\title{
Using groundwater age and hydrochemistry to understand sources and dynamics of nutrient contamination through the catchment into Lake Rotorua, New Zealand
}

\author{
U. Morgenstern ${ }^{1}$, C. J. Daughney ${ }^{1}$, G. Leonard ${ }^{1}$, D. Gordon ${ }^{2}$, F. M. Donath ${ }^{3,4}$, and R. Reeves ${ }^{4}$ \\ ${ }^{1}$ GNS Science, P.O. Box 30368, Lower Hutt, New Zealand \\ ${ }^{2}$ Hawke's Bay Regional Council, Private Bag 6006, Napier, New Zealand \\ ${ }^{3}$ Department of Applied Geology, Georg-August-Universität Göttingen, Goldschmidtstr. 3, 37077 Göttingen, Germany \\ ${ }^{4}$ GNS Science, Private Bag 2000, Taupo, New Zealand
}

Correspondence to: U. Morgenstern (u.morgenstern@gns.cri.nz)

Received: 18 July 2014 - Published in Hydrol. Earth Syst. Sci. Discuss.: 28 August 2014

Revised: 22 December 2014 - Accepted: 10 January 2015 - Published: 5 February 2015

\begin{abstract}
The water quality of Lake Rotorua has steadily declined over the past 50 years despite mitigation efforts over recent decades. Delayed response of the groundwater discharges to historic land-use intensification 50 years ago was the reason suggested by early tritium measurements, which indicated large transit times through the groundwater system. We use the isotopic and chemistry signature of the groundwater for detailed understanding of the origin, fate, flow pathways, lag times and future loads of contaminants. A unique set of high-quality tritium data over more than four decades, encompassing the time when the tritium spike from nuclear weapons testing moved through the groundwater system, allows us to determine detailed age distribution parameters of the water discharging into Lake Rotorua.

The Rotorua volcanic groundwater system is complicated due to the highly complex geology that has evolved through volcanic activity. Vertical and steeply inclined geological contacts preclude a simple flow model. The extent of the Lake Rotorua groundwater catchment is difficult to establish due to the deep water table in large areas, combined with inhomogeneous groundwater flow patterns.

Hierarchical cluster analysis of the water chemistry parameters provided evidence of the recharge source of the large springs near the lake shore, with discharge from the Mamaku ignimbrite through lake sediment layers. Groundwater chemistry and age data show clearly the source of nutrients that cause lake eutrophication, nitrate from agricultural activities and phosphate from geologic sources. With a naturally high phosphate load reaching the lake continuously
\end{abstract}

via all streams, the only effective way to limit algae blooms and improve lake water quality in such environments is by limiting the nitrate load.

The groundwater in the Rotorua catchment, once it has passed through the soil zone, shows no further decrease in dissolved oxygen, indicating an absence of bioavailable electron donors along flow paths that could facilitate microbial denitrification reactions. Nitrate from land-use activities that leaches out of the root zone of agricultural land into the deeper part of the groundwater system must be expected to travel with the groundwater to the lake.

The old age and the highly mixed nature of the water discharges imply a very slow and lagged response of the streams and the lake to anthropogenic contaminants in the catchment, such as nitrate. Using the age distribution as deduced from tritium time series data measured in the stream discharges into the lake allows prediction of future nutrient loads from historic land-use activities 50 years ago. For Hamurana Stream, the largest stream to Lake Rotorua, it takes more than a hundred years for the groundwaterdominated stream discharge to adjust to changes in landuse activities. About half of the currently discharging water is still pristine old water, and after this old water is completely displaced by water affected by land use, the nitrogen load of Hamurana Stream will approximately double. These timescales apply to activities that cause contamination, but also to remediation action. 


\section{Introduction}

Detailed information on groundwater age distribution is required for the Lake Rotorua catchment to understand the agricultural contaminant loads that travel from land to the lake with the groundwater and discharge via springs and streams into the lake, with a large lag time. The water quality of Lake Rotorua has declined continuously over the past 50 years, despite cessation of direct-to-lake sewage discharge in 1991 (Burger et al., 2011) and the fencing-off of streams in grazing land in parts of the lake catchment.

Land use in the catchment has intensified significantly over the past 60 years and is now predominantly forest (39\%), pasture (27\%) and dairy (9\%) (Burger et al., 2011; Rutherford et al., 2009). Increasing nitrate concentrations had been observed in virtually all of the major streams flowing into the lake during the period 1968-2003 (Hoare, 1987; Rutherford, 2003). We measured nitrate concentrations of 6$10 \mathrm{mg} \mathrm{L}^{-1} \mathrm{NO}_{3}-\mathrm{N}$ in three young groundwater samples under dairy farms in the SE catchment. In the absence of significant overland runoff, nutrients from land use are transported with the water through the groundwater system to the lake. Early tritium measurements indicated large transit times through the groundwater system (the subject of this study). With a time lag $>50$ years in the groundwater system, nitrate loads to the lake may be expected to increase further in the future due to delayed arrival of nutrients from historic land use as they ultimately discharge from the groundwater system via the springs and streams into the lake. This trend will be exacerbated by any further intensification of land use within the catchment over recent decades, as this recently recharged water has largely not yet reached the streams (Morgenstern and Gordon, 2006).

Groundwater age is a crucial parameter for understanding the dynamics of the groundwater and the contaminants that travel with the water. Determining water age, and hence transit times, allows identification of delayed impacts of past and present land-use practices on water quality (Böhlke and Denver, 1995; Katz et al., 2001, 2004; McGuire et al., 2002; MacDonald et al., 2003; Broers, 2004; Moore et al., 2006), and for identification of anthropogenic versus geologic impacts on groundwater quality (Morgenstern and Daughney, 2012). Understanding the dynamics of groundwater is fundamental for most groundwater issues. Water age is defined by the transit time of water through catchments and hence is vital for conceptual understanding of catchment processes such as response to rainfall, stream flow generation, recharge source and rate (McGuire and McDonnell, 2006; Morgenstern et al., 2010, 2012; Stewart et al., 2010; Cartwright and Morgenstern, 2012). Water age, being directly related to fluid flux, is also very useful for calibrating numerical surface water and groundwater transport models (Goode, 1996; Burton et al., 2002; Molson and Frind, 2005; Bethke and Johnson, 2008). Water age provides important information on vulnerability to contamination and can therefore be used to assess the se- curity of drinking water supplies, particularly from groundwater bores (Darling et al., 2005; Morris et al., 2005; New Zealand Ministry of Health, 2008). Water age measurements can also be used to quantify rates of hydrochemical evolution resulting from water-rock interaction (Katz et al., 1995; Burns et al., 2003; Glynn and Plummer, 2005; Daughney et al., 2010; Beyer et al., 2014). These applications of water dating cover the spectrum from applied water resource management to fundamental scientific research.

In all of the above-mentioned applications it is important to constrain not only the mean age of water, but also the distribution of ages within a sample from the groundwater discharge. Transit time determinations in catchment hydrology typically identify a range of water ages contributing to stream flow, and the time- and location-dependent distribution of transit times provides insight into the processes that generate runoff (Maloszewski and Zuber, 1982; McGuire and McDonnell, 2006; Stewart et al., 2007; McDonnell et al., 2010). Use of water age determinations for calibration of numerical transport models must also account for the full distribution of age and its variation in space and time (Goode, 1996; Cornaton et al., 2011; Cornaton, 2012). Assessment of the security of drinking water from groundwater bores also requires an understanding of the water's age distribution (Eberts et al., 2012; Morgenstern, 2004). For example, New Zealand legislation states that a water supply bore is considered secure (unlikely to have a risk of contamination by pathogenic organisms) when less than $0.005 \%$ of the water has been present in the aquifer for less than 1 year (New Zealand Ministry of Health, 2008).

For the Lake Rotorua catchment study, tritium is the tracer of choice. Tritium dating can be applied to both river/stream water and groundwater, whereas gas tracers are less suitable for surface waters that are in contact with air. Tritium ages, in contrast to gas tracer ages, include travel through the unsaturated zone (Zoellmann et al., 2001; Cook and Solomon, 1995); travel times can be $>40$ years through the thick unsaturated zones of the Rotorua catchment ignimbrite aquifers (Morgenstern et al., 2004). Tritium is not subject to transformation, degradation or retardation during water transport through the catchment. Tritium dating is applicable to water with mean residence times of up to about 200 years (Cook and Solomon, 1997; Morgenstern and Daughney, 2012), as is typical of New Zealand's dynamic surface waters and shallow groundwaters. In addition, monitoring the movement of the pulse-shaped bomb-tritium through groundwater systems is an excellent opportunity to obtain information about the age distribution parameters of the groundwater. This is particularly useful in groundwater systems, such as the Rotorua system, that have high uncertainties within flow models due to a deep water table and preferential flow paths. Finally, tritium is a particularly sensitive marker for study of the timing of nitrate contamination in groundwater, because the main anthropogenic nitrate contamination of groundwater systems started coincidentally with the bomb-tritium peak 
from the atmospheric nuclear weapons testing after WWII; water recharged before this post-war upsurge in intensive agriculture has low tritium and low nitrate concentrations.

For the Rotorua catchment we have an extensive data set available over time and space. Tritium time series data for the main lake inflows cover more than 4 decades, and data covering the last decade are available with an extremely high spatial resolution of about 100 sites in the Lake Rotorua catchment. Tritium concentration can be measured at GNS Science with the required extremely high accuracy using 95-fold electrolytic enrichment prior to ultralow-level liquid scintillation spectrometry (Morgenstern and Taylor, 2009). Tritium is highly applicable for groundwater dating in the postbomb low-tritium environment of the Southern Hemisphere, as bomb tritium from atmospheric thermonuclear weapons testing has now been washed out from the atmosphere for 20 years, as is described in detail in Morgenstern and Daughney (2012).

The objective of this study is to understand the origin, fate, flow pathways, lag times, and future loads of contaminants that cause lake eutrophication in the Lake Rotorua catchment, central North Island, New Zealand. This will assist in mitigating the deterioration in lake water quality since the 1960s (Rutherford et al., 1989) that threatens the lake's significant cultural and tourist value. Environmental hydrochemistry tracers and age tracers are used to identify the recharge source of the main water discharges to Lake Rotorua, to identify the source of the contaminants (anthropogenic versus geologic), and to evaluate the water age distributions in order to understand groundwater processes, lag times, and the groundwater flow dynamics. The Rotorua groundwater system is complicated due to the catchment's highly complex geology, which has evolved through volcanic activity, and due to the deep water table of $>50 \mathrm{~m}$ in large areas, which prevents detailed groundwater studies and introduces uncertainty in catchment boundaries and flow patterns. The complex geology leads to inhomogeneous groundwater flow patterns, as indicated by large parts of the catchment having particularly large positive or negative specific water yields (White et al., 2004). The groundwater discharge in the northern catchment is unusually large for the size of the surface water catchment, probably due to preferential flow paths that route groundwater towards the north across the surface slope in this part of the catchment.

The tritium and age distribution data are currently being used to calibrate a numeric groundwater transport model. The use of this rich data set for groundwater transport model calibration is part of a larger investigation that evaluates the calibration of hydrological and hydrogeological models using hydrochemical data, including tracers of water age, with the aim of using tracer-calibrated groundwater models for nutrient transport and economic modelling (e.g. Lock and Kerr, 2008; Rutherford et al., 2009), ultimately supporting optimal and sustainable land and water management in catchments. The broader findings from the Rotorua investigation will be applied to the many other New Zealand catchments for which time series age tracer data are available (Stewart and Morgenstern, 2001; Morgenstern, 2004; Stewart and Thomas, 2008; Gusyev et al., 2014).

\section{Hydrogeological setting}

\subsection{Geology}

Lake Rotorua is located in a roughly circular caldera basin in the central North Island, New Zealand (Fig. 1), situated in the Taupo Volcanic Zone (TVZ), an area of silicic volcanism with NW-SE extension and geothermal activity roughly $60 \mathrm{~km}$ wide by $300 \mathrm{~km}$ long that is related to subduction of the Pacific plate beneath the Australian plate off New Zealand's east coast (Wilson et al., 1995; Spinks et al., 2005). Figure 1 shows the surficial geology. Mesozoic greywacke, which outcrops to the east and west of the TVZ, forms the basement rocks in the area. Younger formations are predominantly rhyolite ignimbrites, rhyolite and dacite lava domes, and lacustrine and alluvial sediments derived from these volcanic lithologies. Note that "rhyolite" is sometimes used colloquially to refer to rhyolite lava, but the use of "rhyolite" is here applied only as a formal compositional definition (volcanic rocks $>69 \% \mathrm{SiO}_{2}$ ). Deposits of rhyolite composition may be pyroclastic (explosively formed, including airfall deposits and the pyroclastic flow deposit termed "ignimbrite") or they may be lavas (effusively erupted without explosion). Rhyolite lavas are viscous and often push up into high lava domes over the eruption vent. The geological formations and processes of greatest relevance to the hydrology and hydrogeology of the Lake Rotorua catchment area are shown in the three-dimensional geological model of White et al. (2004) (Fig. 2) and summarized in the following paragraphs.

From 2 million to 240 thousand years ago (ka), a number of rhyolite lava domes were emplaced and volcanic activity from TVZ calderas resulted in pyroclastic deposits across the area, including the highly welded Waiotapu ignimbrite (ca. $710 \mathrm{ka}$; "older ignimbrite" in Fig. 1) and a range of variably welded, variably altered, sometimes-jointed ignimbrites of which the Matahina, Chimp and Pokai formations (ca. 320-270 ka) are most significant and mapped within "undifferentiated rhyolite pyroclastics" in Fig. 1. These ignimbrites are expected to be the main basal units for groundwater aquifers in the study area (White et al., 2004).

The period from 240 to $200 \mathrm{ka}$ is defined by the eruption that deposited the Mamaku Plateau Formation (240 ka) and formed the Rotorua Caldera. The caldera collapse downfaulted parts of older lava domes positioned across the western and northern edge of the caldera. The Mamaku Plateau Formation is predominantly composed of ignimbrite (hereafter "Mamaku ignimbrite"), which is variably welded, variably jointed and very permeable. Several rhyolite lava domes (mainly Ngongotaha and its neighbours) began to develop 


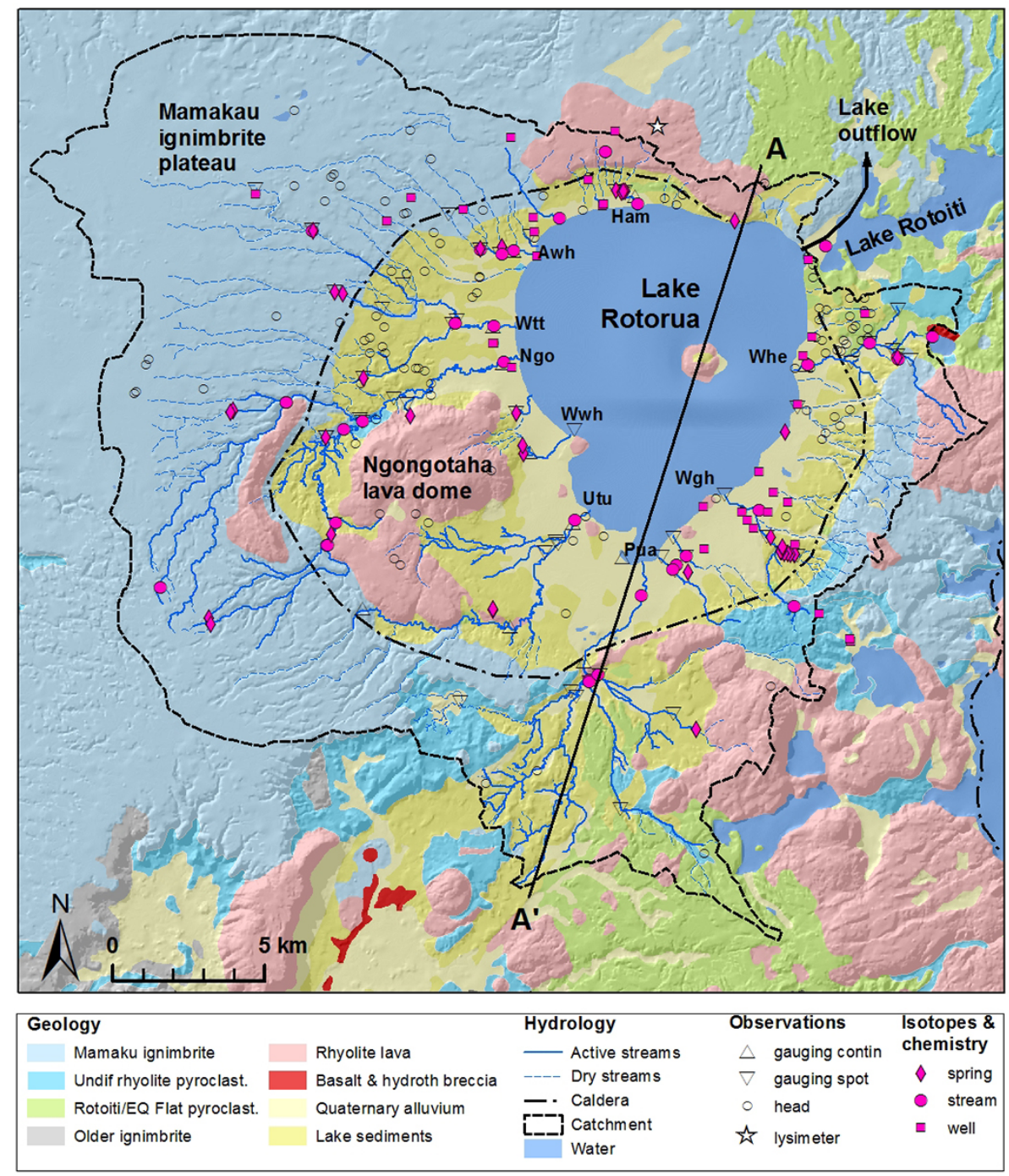

Figure 1. Location and geology of the Lake Rotorua catchment, with sampling sites. The assumed groundwater catchment is from White and Rutherford (2009). Surficial geology is based on the 1:250000 map of Leonard et al. (2010). For abbreviations of the names of the major streams refer to Table 1. The approximate trace of the caldera is shown. Cross-section $\mathrm{A}^{\prime}-\mathrm{A}$ is shown on the cut-away face of Fig. 2.

soon after the caldera collapse. Also, soon after the eruption, a lake began to form in the collapsed depression, leading to the deposition of lacustrine fine ash and pumice, commonly referred to as lacustrine sediments (Leonard et al., 2010); note that these sediments have sometimes been referred to as Huka or Huka Group sediments throughout the TVZ, but this definition formally refers only to specific units near Taupo City and the term Huka is avoided here.

From 200 to $61 \mathrm{ka}$, volcanic activity in the vicinity of Lake Rotorua was relatively subdued. A number of eruptions from the Okataina Volcanic Centre (OVC), located to the east of the Rotorua caldera, produced widely dispersed but relatively thin airfall deposits. These pyroclastic materials caused periodic damming of drainage pathways and led to fluctuations in lake level that in turn resulted in widespread and variably thick sediments being deposited in the Rotorua Caldera. This period of relatively quiet volcanic activity ended with the Rotoiti and Earthquake Flat eruptions from the OVC, which produced widespread pyroclastic deposits, including the nonwelded ignimbrites of the Rotoiti Formation and the Earthquake Flat Formation.

From 61 ka to present, numerous eruptions from the OVC (the most recent of which was in 1886) deposited airfall layers in the Lake Rotorua catchment area. Numerous rhyolite lava units were also emplaced during this period. The periodic deposition of pyroclastic materials, along with activity on faults of the Taupo Rift (Leonard et al., 2010), presumably caused fluctuations in the lake level, with current lake level being reached sometime within the last few thousand years (White et al., 2004). Due to the decline of lake 
level, Holocene alluvial sand and gravel deposits are found in stream channels and around the current lake shoreline.

The southern Rotorua basin hosts a vigorous geothermal system producing many hot water, hot mud, steam and geyser features, along with gas emission, between the southern edge of the Lake and about the southern edge of the caldera (Fig. 1). There is hot local groundwater flow in this area, generally flowing down-hill northwards into the lake. Beyond this relatively confined area the groundwater system does not appear to interact with fluids from this geothermal system.

\subsection{Hydrology}

Lake Rotorua has a surface area of $79 \mathrm{~km}^{2}$ and a mean depth of $10.8 \mathrm{~m}$ (Burger et al., 2011), with a total water volume of $0.85 \mathrm{~km}^{3}$. The assumed total catchment area is ca. $475 \mathrm{~km}^{2}$ (White and Rutherford, 2009) (Fig. 1).

Annual rainfall in the catchment is strongly affected by topography and varies from more than $2200 \mathrm{~mm}$ northwest of the lake to less than $1400 \mathrm{~mm}$ southeast of the lake (Hoare, 1980; White et al., 2007; Rutherford et al., 2008). Approximately $50 \%$ of rainfall infiltrates into the groundwater system. This is based on two sources of information: (1) comparisons of rainfall and actual evapotranspiration that have been made for various parts of the catchment (Hoare, 1980; Dell, 1982; White et al., 2004, 2007; Rutherford et al., 2008); and (2) data from paired lysimeters, a standard rain gauge and a ground-level rain gauge installed at Kaharoa (White et al., 2007) (Fig. 1). With $50 \%$ of rainfall recharge, total infiltration into the groundwater system is estimated to be $14500 \mathrm{~L} \mathrm{~s}^{-1}$, based on the catchment shown in Fig. 1, excluding rainfall inputs direct to the lake, and assuming recharge is $50 \%$ of rainfall. This rainfall recharge supports stream flow and potentially direct inputs of groundwater to the lake.

There are nine major streams (Fig. 1, for abbreviations refer to Table 1) and several minor streams that flow into the lake; the remainder of the inflows are provided from direct inputs of rainfall and lake-front features, and potentially from groundwater seepage through the lake bed. The major streams are baseflow-controlled and characterized by very constant water flow (Hoare, 1980) and temperature, and groundwater-derived baseflow accounts for approximately $90 \%$ of the average flow in the typical Rotorua stream (Hoare, 1987). Baseflows in the nine major streams entering Lake Rotorua cumulatively amount to $11800 \mathrm{~L} \mathrm{~s}^{-1}$, and total inflows to the lake from minor streams and lake-front features amounts to $350 \mathrm{~L} \mathrm{~s}^{-1}$ (Hoare, 1980; White et al., 2007) (Table 1).

With the lake water volume of $0.85 \mathrm{~km}^{3}$, the lake water turnover time via the groundwater-fed streams is 2.2 years. The only surface outflow occurs through Ohau Channel via Lake Rotoiti (Fig. 1). Water balance calculations suggest that the total catchment area exceeds the surface water catchment area (White et al., 2007); in other words, groundwater

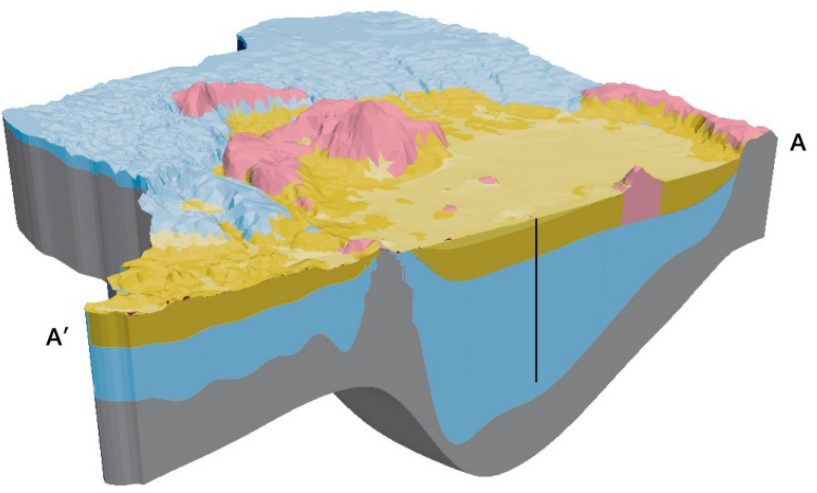

Figure 2. Three-dimensional geological model of the Lake Rotorua catchment area (from White et al., 2007). The location of the vertical cut-away face $\mathrm{A}^{\prime}-\mathrm{A}$ is shown in Fig. 1 . The vertical exaggeration is $5 \times$, with a $1 \mathrm{~km}$ vertical scale bar shown in the centre. The colour scheme is similar to that in Fig. 1 (bottom to top): pre-Mamaku formations (grey), Mamaku Plateau Formation (light blue), sediment formation (dark yellow), lava domes (red) and Holocene alluvial deposits (light yellow).

from outside the surface water catchment is flowing through the aquifer system to Lake Rotorua (White and Rutherford, 2009).

\subsection{Hydrogeology}

Groundwater flow in the Lake Rotorua catchment is influenced by several fundamental geological characteristics. First, the Mamaku ignimbrite, the dominant hydrogeological feature in the catchment, is assumed to be up to $1 \mathrm{~km}$ thick in the centre of the caldera depression, and from about 200 to tens of metres thick outside of the caldera, decreasing generally with distance from the caldera (Fig. 2). Ignimbrite tends to fill in pre-existing valleys and landforms, so its thickness can be quite variable over horizontal distances of as little as hundreds of metres. Transit times of groundwater through such a thick aquifer may be lengthy compared to times in the shallow alluvial aquifers used for water supply in many other parts of the world and New Zealand. Second, the ignimbrites in the Lake Rotorua catchment are known to be variably welded, altered and jointed, with the potential for preferential groundwater flow paths. Groundwater may be routed from its recharge area along lengthy preferential flow paths and discharge in neighbouring surface catchments, leading to water ages that vary substantially even within a localized area (the presence of such preferential flow paths can therefore be demonstrated with age tracers). Third, the broadly circular collapse faults of the caldera constitute a major structural feature that may influence the flow of groundwater within the catchment.

The major water contribution to Lake Rotorua is from the western catchment that drains the eastern flanks of the Mamaku Plateau (Fig. 1). The Mamaku ignimbrite formation 
Table 1. Estimates of baseflow from White et al. (2007). Abbreviations refer to Fig. 1.

\begin{tabular}{llr}
\hline Stream & Abbreviation & $\begin{array}{r}\text { Baseflow } \\
\left(\mathrm{L} \mathrm{s} \mathrm{s}^{-1}\right)\end{array}$ \\
\hline Hamurana & Ham & 2750 \\
Awahou & Awh & 1700 \\
Waiteti & Wtt & 1300 \\
Ngongotaha & Ngo & 1700 \\
Waiowhiro & Wwh & 370 \\
Utuhina & Utu & 1600 \\
Puarenga & Pua & 1700 \\
Waingaehe & Wgh & 250 \\
Waiohewa & Whe & 390 \\
Minor streams & n/a & 350 \\
\hline
\end{tabular}

serves as a major source of groundwater in the area (Gordon, 2001). A large area $\left(\sim 250 \mathrm{~km}^{2}\right)$ is drained by several major springs $\left(>1000 \mathrm{~L} \mathrm{~s}^{-1}\right)$ emerging from the ignimbrite on the western side of Lake Rotorua. Given the large extent and thickness of the ignimbrite aquifer, a large groundwater reservoir exists, with long water residence times expected in the aquifer. Taylor and Stewart (1987) estimated the mean residence time of the water of some of the springs as 50 100 years.

The post-240 ka ignimbrites in this area (and some lava domes) are extremely porous; they sustain hardly any overland water flow (Dell, 1982), with most of the stream beds dry throughout most of the year except during heavy rain, and they allow the infiltrated water to percolate down to an extremely deep groundwater table $>50 \mathrm{~m}$ (the ignimbrite formations around Ngongotaha Dome are an exception).

Little is known about the hydrogeology of the groundwater system; borehole data collected by drillers is often not of sufficient quality to identify and correlate aquifer units. Rosen et al. (1998) developed a schematic model for the Mamaku ignimbrite, with a lower and upper ignimbrite aquifer sheet considered permeable, and a middle sheet considered impermeable but fractured and not acting as an aquitard for the other two sheets. This is probably an over-simplification in many areas (see Milner et al., 2003) but does point at horizontally planar discontinuities within the formation that appear to influence groundwater flow. The water, after easy passage through the large aquifer, is forced to the surface only $1-2 \mathrm{~km}$ before the lake shore via large groundwater springs, feeding large streams that drain into Lake Rotorua.

The water-bearing lava dome formations that predate the Mamaku ignimbrite are likely to have fracture flow, based on spring discharge permeability analysis, varying depending on fracture sizes and linkages. Faulting associated with the Rotorua caldera has offset several of the rhyolite domes and groundwater may flow through these faults.

The palaeo-lake sediments that post-date the Mamaku ignimbrite and rhyolite lava formations comprise silt, sand and gravel (ignimbrite, obsidian and rhyolite pumice) and are considered permeable, with lenses of low permeability that can also act as confining layers.

Overall, understanding of the Rotorua groundwater system is complicated due to the highly complex geology that has evolved through volcanic activity. Vertical and steeply inclined geological contacts are common, precluding a simple horizontal-layer-based succession model throughout the catchment usually applicable in sedimentary basins. Aquifers have not been well determined due to insufficient bore log data, and also the extent of the Lake Rotorua groundwater catchment is difficult to establish, due to the deep water table of $>50 \mathrm{~m}$ in large areas at the catchment boundaries, combined with an inhomogeneous groundwater flow pattern, as indicated by the groundwater discharge in the northern catchment being too large compared to the size of the surface water catchment.

\section{Methods}

\subsection{Determination of water age}

The age of the groundwater at the discharge point characterizes the transit time of the water through a groundwater system. For groundwater dating, we use tritium time series (repeated sampling after several years), and the complementary tracers tritium, $\mathrm{CFCs}$ and $\mathrm{SF}_{6}$ together where possible. The method of dating young groundwater with mean ages of less than 200 years for current New Zealand Southern Hemispheric conditions is described in detail in Morgenstern and Daughney (2012, Sects. 2.3 and 2.4). In short: tritium dating, in previous decades problematic due to interference from the artificial tritium produced by atmospheric nuclear weapons testing in the early 1960s, has now become very efficient and accurate due to the fading of the bomb-tritium.

For groundwater dating, one or more tracer substances are measured that have a time-dependent input into the groundwater system or a well-defined decay-term (e.g. radioactive decay). The tracer concentration data are then fitted using a lumped-parameter model (Maloszewski and Zuber, 1982; Zuber et al., 2005). For dating young groundwater - i.e. water less than about 100 years - the most commonly used tracers are tritium, chlorofluorocarbons (CFCs) and sulfur hexafluoride $\left(\mathrm{SF}_{6}\right)($ Cook and Solomon, 1997; Edmunds and Smedley, 2000; Stewart and Morgenstern, 2001; Morgenstern et al., 2010). The measured output tracer concentration in the groundwater $\left(C_{\text {out }}\right)$ is then compared to its tracer concentration at the time of rainfall input $\left(C_{\text {in }}\right)$ using the convolution integral

$$
C_{\text {out }}(t)=\int_{0}^{\infty} C_{\text {in }}(t-\tau) e^{-\lambda \tau} g(\tau) \mathrm{d} \tau,
$$


where $t$ is the time of observation, $\tau$ is the transit time (age), $e^{-\lambda \tau}$ is the decay term with $\lambda=\ln (2) / T_{1 / 2}$ (e.g. radioactive decay of tritium with a half-life $T_{1 / 2}$ of 12.32 years) and $g(\tau)$ is the system response function (Cook and Herczeg, 1999; Zuber et al., 2005).

The system response function accounts for the distribution of ages within the water sample, for example from mixing of groundwater of different ages within the aquifer, or at the well (Maloszewski and Zuber, 1982, 1991; Goode, 1996; Weissman et al., 2002; Zuber et al., 2005). The two response functions most commonly used are the exponential piston flow model and the dispersion model (Zuber et al., 2005). The exponential piston flow model combines the piston flow model, assuming piston flow within a single flow tube in which there is minimal mixing of water from different flow lines at the discharge point (e.g. confined aquifer), and the exponential model, assuming full mixing of water from different flow paths with transit times at the groundwater discharge point that are exponentially distributed (e.g. mixing of stratified groundwater at an open well in an unconfined aquifer). The response functions of the various models are described in Maloszewski and Zuber (1982) and Cook and Herczeg (1999). To interpret the ages of the Lake Rotorua catchment data set, the exponential piston flow model was used, given by

$g=0$ for $\tau<T(1-f)$

$g=\frac{1}{T f} e^{\left(-\frac{\tau}{T f}+\frac{1}{f}-1\right)}$ for $\tau \geq T(1-f)$,

where $T$ is the mean residence time (MRT), $f$ is the ratio of the volume of exponential flow to the total flow volume at the groundwater discharge point, and $T(1-f)$ is the time it takes the water to flow through the piston flow section of the aquifer (Maloszewski and Zuber (1982) use the variable $\eta$; $\eta=1 / f)$. When $f=0$ the model becomes equivalent to the piston flow model, and when $f=1$ it becomes equivalent to the exponential model.

The two parameters of the response functions, the MRT and the distribution of transit times $(f)$, are determined by convoluting the input (tritium concentration in rainfall measured over time) to model water passage through the hydrological system in a way that matches the output (e.g. tritium concentrations measured in wells or springs). Because of its pulse-shaped input, tritium is a particularly sensitive tracer for identifying both of these two parameters, which can be deduced uniquely by comparing the delay and the dispersion of the bomb-pulse tritium in the groundwater to that from tritium in the original rain input. This method is particularly useful for interpretation of ages of groundwater in the Lake Rotorua catchment, where most of the groundwater discharges lack any other information on mixing of groundwater with varying flow path lengths and of different age, such as ratio of confined to unconfined flow volume, or screen depth for wells.
For tracer age interpretation, the integral (Eq. 1) was used to convolute the historical rainfall tracer input to an output that reflects mixing in a groundwater system, with the best match of the simulated output to the measured output time series data (Fig. 3). The TracerLPM workbook (Jurgens et al., 2012) was used. The tritium input function is based on concentrations of tritium in rainfall measured monthly since the 1960s at Kaitoke, near Wellington, New Zealand (Morgenstern and Taylor, 2009). The Kaitoke rainfall input function is multiplied by a scaling factor of 0.87 to account for variation in atmospheric tritium concentrations due to latitude and orographic factors, as deduced from measurements from rain at various locations in New Zealand (e.g. Morgenstern et al., 2010). For the prevailing New Zealand climatic conditions there is no need for correction of the tritium input for seasonal infiltration (Morgenstern et al., 2010).

The problem of ambiguity in tritium dating over the last decades is demonstrated in Fig. 3. Hangarua Spring discharges old water with a mean residence time of about 90 years (see below), but during the late 1980s its tritium concentration was similar to that of very young water (rain curve in Fig. 3). At that time, the tritium concentration in Hangarua Spring would have been in agreement with both very young water and old water with a mean residence time of 90 years. Tritium data covering several decades, however, clearly distinguish this old water (low tritium concentration) from young rain water. Figure 3 also shows that due to the fading of the bomb-tritium in recent decades (tritium decay over four tritium half-lives since the bomb spike), in recent years the tritium concentration of old water is clearly distinguishable (lower) from that of young water, without ambiguity. The tritium time series data allow also for constraining groundwater mixing models. Figure 3 shows the model output curves that match the measured tritium data. Given sufficient analytical accuracy, this is also possible for extremely low tritium concentrations; the data for Hamurana water intake spring (blue in Fig. 3) are all below $0.4 \mathrm{TU}$, which is below the detection limit of many tritium laboratories (http:// www-naweb.iaea.org/napc/ih/IHS_programmeihltric.html).

The application of mixing models is described in Morgenstern and Daughney (2012, Sect. 2.6). Throughout New Zealand, for springs and wells in almost all hydrogeological situations, the exponential piston flow model, with its age distribution, has produced good matches to most (about a hundred) tritium time series data. It was not, however, possible to obtain adequate matches in the ignimbrite area of the Rotorua catchment using such a simple exponential piston flow model. Alternatively, using the dispersion model did not improve the matches. The complex volcanic aquifers of the Lake Rotorua catchment, which have evolved through volcanic activity, require a more complex system response function. A combination of two exponential piston flow models was used. 


\subsection{Sample collection and analysis}

Samples were collected from 41 springs, from 31 groundwater-dominated stream flow sites, and from 26 groundwater wells. To obtain the residence times of the water discharging into the lake after passage through the entire groundwater system, sampling focused on the naturally flowing groundwater discharges, the springs and streams. Samples were collected at times of base flow conditions.

All nine major streams were sampled multiple times near the inflow into the lake, typically 3-4 times (Figs. 3 and 4). Most of these tritium time series go back to the early 1970s and encompass the passage of the "bomb" tritium peak through the groundwater system, allowing determination of detailed age distribution parameters for these major inflows to the lake. These "historic" samples had been collected sporadically for various projects over the decades to study the transfer of the bomb-tritium through the hydrologic cycle. Over the recent decade, the streams have also been sampled for tritium at various points upstream, at various main confluences, or at main springs to obtain a detailed spatial distribution of water ages. Springs and wells were also once sampled for $\mathrm{CFCs}_{2} \mathrm{SF}_{6}$, argon and nitrogen, to obtain complementary age information.

Sampling locations are shown in Fig. 1. Many of the sites have no road access, with some of them in remote steep gullies. A portable sampling system was required for the gas samples to allow fresh water from the well or spring to be pumped into the sample bottles from below the water surface without air contact. We used a pneumatic Bennet pump, powered from a cylinder of compressed air at the remote locations, and from a compressor powered by the car battery at sites with car access. Sampling from streams (tritium only) involved simply dipping the bottle under the water surface and filling the bottle.

Sampling methods for hydrochemistry and nutrients were according to Daughney et al. (2007). Age tracer samples were collected without filtration or preservation. For tritium, a $1 \mathrm{~L}$ plastic bottle was filled to the top. For CFC samples, two $125 \mathrm{~mL}$ glass bottles with aluminium liner cap were filled, rigorously excluding air contact by filling from the bottom via a nylon tube and three times volume replacement below the surface of the overflowing sample water. $1 \mathrm{~L}$ bottles were filled for $\mathrm{SF}_{6}$.

Analytical details for hydrochemistry are described in Daugney et al. (2007). Details of the tritium analysis procedure are described in Morgenstern and Taylor (2009). While the early tritium measurements in the 1970 s were performed with a detection limit of approximately 0.1 Tritium Units (TU), we now achieve significantly lower detection limit of 0.02 (TU) via tritium enrichment by a factor of 95 and reproducibility of tritium enrichment of $1 \%$ via deuterium calibration. Analysis procedures for CFC11, CFC-12, and $\mathrm{SF}_{6}$ are described in van der Raaij and

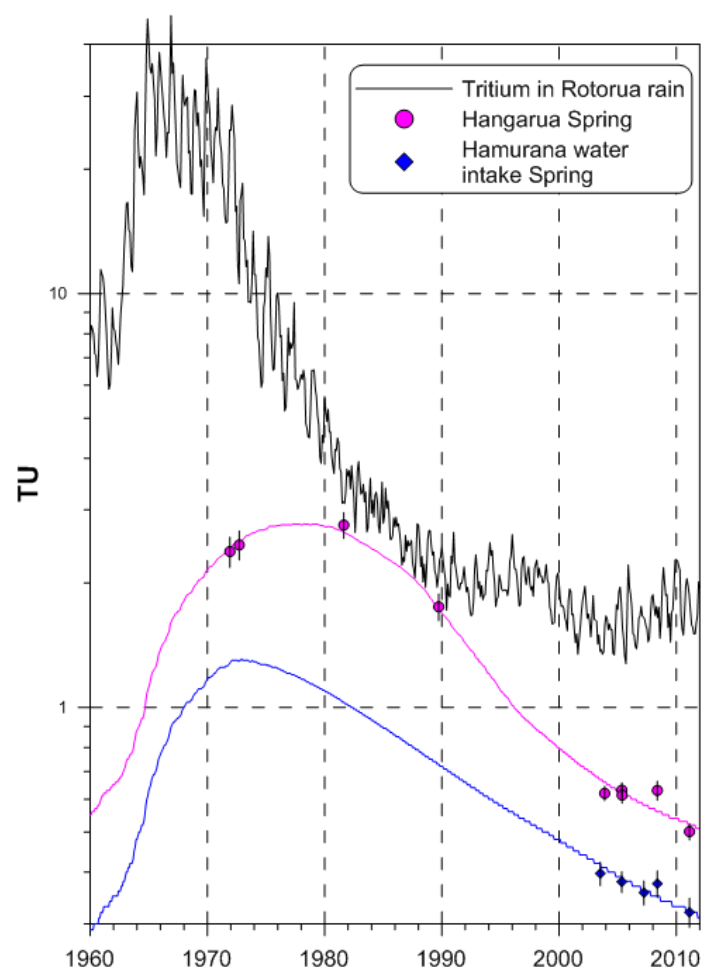

Figure 3. Tritium rain input for the Rotorua catchment, and measured tritium output at Hangarua Spring and at Hamurana water intake spring. The input curve is based on monthly measurements in Kaitoke near Wellington, New Zealand, scaled to the latitude of Rotorua with a factor 0.87 , and smoothed by an exponential piston flow model with 0.3 years mean residence time and $50 \%$ exponential flow within the total flow volume. One TU=one tritium atom per $10^{18}$ hydrogen atoms. For the spring samples one-sigma measurement errors are shown. Note the logarithmic scale of the TU axis.

Beyer (2014). Detection limits are $3 \times 10^{-15} \mathrm{~mol} \mathrm{~kg}^{-1}$ for CFCs and $2 \times 10^{-17} \mathrm{~mol} \mathrm{~kg}^{-1}$ for $\mathrm{SF}_{6}$. Dissolved argon and nitrogen concentrations were measured for estimating the temperature at the time of recharge, and the excess air concentration, as described by Heaton and Vogel (1981), for calculation of the atmospheric partial pressure (ppt) of CFCs and $\mathrm{SF}_{6}$ at the time of recharge.

\section{Results and discussion}

In the following section hydrochemistry cluster analysis and hydrochemistry evolution are discussed to assess the geographic sources of groundwater and groundwater processes in the aquifer. The nutrients nitrate, sulfate, potassium and phosphate are discussed to evaluate their source (anthropogenic versus geologic), lag time, fate and impact on lake eutrophication. The age distributions of the groundwater discharges to Lake Rotorua are discussed to understand the conceptual groundwater flow pattern and the lag time in the 


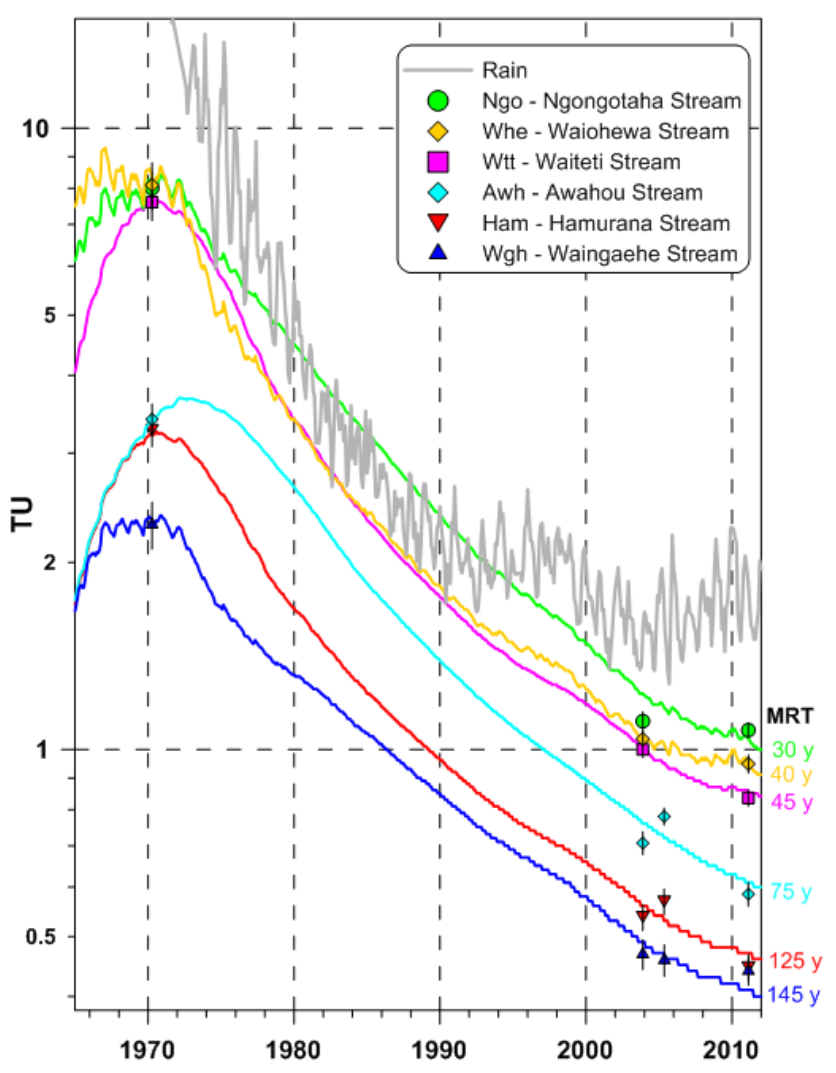

Figure 4. Tritium time series data, together with their matching lumped-parameter model outputs, for six major streams. Grey line is tritium input via rain from Fig. 3. The locations of the streams are shown in Fig. 1.

groundwater system. The ultimate goal of this project is the use of the hydrochemistry and groundwater age parameters for calibration of a groundwater transport model for improved management of the nutrient loads to the lake - the subject of follow-up papers.

\subsection{Groundwater age interpretation}

To obtain the unique solution for both parameters of the age distribution for a specific model, time series data are required (Sect. 3.1). Most of the large water inflows into Lake Rotorua have long time series data available (up to over four decades), allowing for well constrained age distribution parameters for both MRT and the fraction $f$ between different flow models (or Péclet number for the dispersion model). The tritium time series data, together with the matching lumpedparameter model simulations, are shown in Fig. 3 for two of the large springs, and in Fig. 4 for six of the large streams (covering $2 / 3$ of stream baseflow to Lake Rotorua). For the sites with shorter time series data (subcatchment stream discharges, groundwater wells), most of the sites have at least sufficient time series or multi-tracer data for unambiguous robust age interpretations. If fraction $f$ cannot be established
Table 2. Age distribution parameters for the two binary exponential piston flow models (EPMs) for the major stream discharges to Lake Rotorua. Average MRT is the mean residence time between the two EPMs.

\begin{tabular}{lrrlllr}
\hline \multirow{2}{*}{ Stream } & \multicolumn{2}{c}{ EPM1 } & Fraction & \multicolumn{2}{c}{ EPM2 } & Average \\
\cline { 2 - 3 } & MRT1 & $\mathrm{f} 1$ & of EPM1 & MRT2 & $\mathrm{f} 2$ & $\begin{array}{r}\text { MRT } \\
\text { [year] }\end{array}$ \\
\hline Hamurana & 185 & 0.82 & 0.65 & 12 & 0.77 & 125 \\
Awahou & 80 & 1.00 & 0.92 & 6 & 0.91 & 75 \\
Waiteti & 60 & 1.00 & 0.78 & 3 & 0.90 & 45 \\
Ngongotaha & 35 & 1.00 & 0.82 & 1 & 0.91 & 30 \\
Waiowhiro & 40 & 0.63 & 1.00 & n/a & n/a & 40 \\
Utuhina & 85 & 0.60 & 0.70 & 1 & 1.00 & 60 \\
Puarenga & 44 & 1.00 & 0.95 & 2 & 1.00 & 40 \\
Waingaehe & 160 & 0.94 & 0.90 & 3 & 1.00 & 145 \\
Waiohewa & 55 & 1.00 & 0.75 & 1 & 1.00 & 40 \\
\hline
\end{tabular}

uniquely from the tritium time series data, we applied mixing models that matched long tritium time series data from other sites with similar hydrogeologic settings to these sites. All 96 sites with tritium time series or tritium and complementary $\mathrm{CFC}$ and $\mathrm{SF}_{6}$ data have unambiguous age interpretation. For the tritium time series data shown in Figs. 3 and 4, the lumped-parameter models, with their respective age distribution parameters that match the measured data, are listed in Table 2.

Throughout New Zealand, and including all hydrogeologic situations (but mainly groundwater wells), we have measured approximately a hundred long tritium time series covering several decades. A simple lumped-parameter model, the exponential piston flow model, usually can match these time series data well (e.g. Morgenstern and Daughney, 2012). The long-term tritium data from most of the large stream discharges shown in Fig. 4, however, cannot be matched by a simple model such as the exponential piston flow or dispersion model and require a more complex groundwater flow model combination. Using a binary mixing model, with parallel contributions from two exponential piston flow models, resulted in excellent matches. We justify this binary mixing model by inferring two different flow contributions in the catchment to stream and spring flow - from deep old groundwater, as indicated by very deep groundwater tables in the area (generally $>50 \mathrm{~m}$ ), and from younger groundwater from shallow aquifers, as indicated by minor stream flows maintained by shallow aquifers. In Table 2 are also listed the average mean residence times between the two parallel models, weighted by their fraction within the total flow. For the MRTs, errors caused by our tritium measurement error and uncertainty in tritium input are typically \pm 1 year for MRTs $<5$ years, \pm 2 years for MRTs between 5 and 10 years, \pm 3 years for MRTs between 10 and 50 years, \pm 5 years for MRTs between 50 and 100 years, and larger errors for older water towards the detection limit. 
For convenience, the average MRTs are also listed in Fig. 4 next to their model output curve. It is obvious from Fig. 4 that all the main streams discharge very old water into Lake Rotorua. The tritium response of the streams is clearly distinguishable from that of young rain water (grey line). The youngest water discharge, Ngongotaha Stream (green), has an average MRT of 30 years. All other main streams discharge significantly older water, up to MRT of 145 years for Waingaehe Stream (dark blue). Note that even though bomb-tritium from atmospheric nuclear weapons testing in the 1960s has decayed enough to no longer cause ambiguous age interpretations, it is still possible to detect the tail of the bomb-tritium for matching model parameters if tritium analyses have sufficient accuracy; all data for the Hamurana water intake spring (blue in Fig. 3) are below 0.4 TU.

Most of the streams and springs discharge very old groundwater into Lake Rotorua, with MRTs typically between 50-150 years, indicating discharge from a large groundwater system with large water residence (turn-over) times. Only a few small subcatchments with minor flow rates discharge young water (MRT $<20$ years), indicating local geologic units below the surface that do not allow water to infiltrate into and flow through larger, deeper groundwater systems.

Substantial fractions of that long residence time in the groundwater system may occur during passage through the thick unsaturated zones $(50-100 \mathrm{~m})$ as indicated by CFC and $\mathrm{SF}_{6}$ results measured at groundwater wells and springs (Morgenstern et al., 2004). CFCs and $\mathrm{SF}_{6}$ in groundwater are still exchanged with the atmosphere during passage through the unsaturated zone, therefore $\mathrm{CFC}$ and $\mathrm{SF}_{6}$ ages represent travel time through the saturated zone only. Large observed differences between $\mathrm{CFC}$ and $\mathrm{SF}_{6}$ ages, compared to tritium ages of up to 40 years and greater for the older waters, therefore indicate travel time of the groundwater through the unsaturated zone of $>40$ years for the older groundwater discharges.

The old age of the majority of the Lake Rotorua water inflows and the highly mixed nature of the water discharges (note the high fractions of exponential flow, up to $100 \%$, in Table 2) implies a very slow and lagged response of the streams and the lake to anthropogenic contaminants in the catchment, such as nitrate. The majority of the nitrate load currently discharging into the lake is thus from land-use activities 30 and more years ago.

About a hundred stream and groundwater well samples have been dated in the Lake Rotorua catchment. The groundwater age distributions are used in the following sections to identify hydrochemistry evolution, sources of contaminants, and to predict future nitrate loads that will enter Lake Rotorua from the large contaminated groundwater system. In a future paper, the conceptual groundwater flow model in the Lake Rotorua catchment will be inferred from the groundwater age distribution data. The data will subsequently be used for calibration of a groundwater transport model.

\subsection{Hydrochemistry and recharge source}

The hydrochemical composition of the groundwater and surface waters in the Rotorua catchment have been investigated by Morgenstern et al. (2004) and Donath et al. (2014); the following section summarizes the results relevant to the present study.

Hydrochemistry is driven by interaction between water and the different major lithologies and can be used to track the origin of the groundwater. Hydrochemistry reflects the rhyolite ignimbrite and lava aquifer lithologies that dominate the Lake Rotorua catchment, with much lower concentrations of $\mathrm{Ca}, \mathrm{Mg}$ and $\mathrm{SO}_{4}$ and much higher concentrations of $\mathrm{F}, \mathrm{PO}_{4}$ and $\mathrm{SiO}_{2}$, compared to groundwater in other parts of New Zealand.

Several statistical and graphical techniques were applied to characterize the variations in hydrochemistry across parts of the catchment. Hierarchical cluster analysis (HCA) was shown to be a useful technique to identify samples with similar hydrochemical composition, and to relate the groundwater samples to their origin from one of the main aquifer lithologic units. HCA conducted with Ward's linkage rule allowed the samples to be partitioned into four hydrochemical clusters. Three of the clusters, accounting for the majority of the samples, were inferred to reflect water-rock interaction with the dominant lithologies in the catchment, namely Mamaku ignimbrite, lava or palaeo-lake sediments. Hydrochemistry inferred to indicate interaction between water and the Mamaku ignimbrite had $\mathrm{Na}$ and $\mathrm{HCO}_{3}$ as the dominant cation and anion, respectively, and among the highest concentrations of $\mathrm{Mg}, \mathrm{PO}_{4}$ and $\mathrm{SiO}_{2}$ and among the lowest concentrations of $\mathrm{F}, \mathrm{K}$ and $\mathrm{SO}_{4}$ observed. Hydrochemistry inferred to indicate interaction between water and rhyolite lava also had $\mathrm{Na}$ and $\mathrm{HCO}_{3}$ as the dominant cation and anion, respectively, but had relatively low concentrations of $\mathrm{PO}_{4}$ and among the highest concentrations of K. Hydrochemistry inferred to indicate interaction between water and sediments had $\mathrm{Na}-\mathrm{Ca}-\mathrm{HCO}_{3}-\mathrm{Cl}$ water type and relatively low concentrations of $\mathrm{SiO}_{2}$. The remaining cluster was inferred to represent geothermal influences on the hydrochemistry (e.g. elevated concentrations of $\mathrm{Na}, \mathrm{Cl}, \mathrm{SO}_{4}, \mathrm{SiO}_{2}$ and $\mathrm{NH}_{4}$ ).

Figure 5 shows the hydrochemical clusters of the water samples inferred to indicate interaction between water and Mamaku ignimbrite (light blue), lava (red) or lacustrine sediments (dark yellow). Note that samples assigned to the cluster inferred to indicate geothermal origin are not displayed in Fig. 5 or discussed further in the present study because geothermal influence is not the subject of this study.

Samples with hydrochemistry indicative of interaction with the Mamaku ignimbrite occur predominantly in the north and northwest portion of the catchment (Fig. 5, blue). All of the large springs discharging into Hamurana (Ham), Awahou (Awh), and Utuhina (Utu) streams have a Mamaku ignimbrite hydrochemistry signature (blue circles). The stream reaches in the Mamaku ignimbrite area upstream 


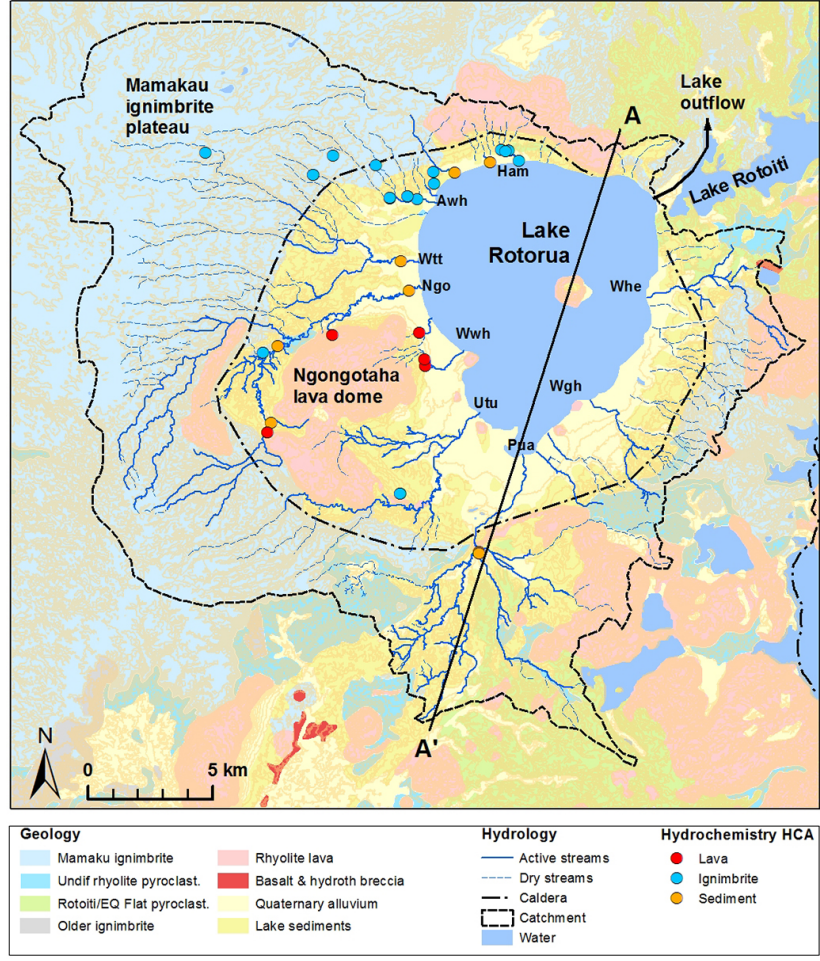

Figure 5. Distribution of hierarchical cluster analysis (HCA) clusters in Lake Rotorua catchment, together with the geological units (Leonard et al., 2010) and stream reaches. Stream reaches shown as dotted lines are usually dry. HCA clusters relate to origin of the groundwater from one of the three main geologic formations: Mamaku ignimbrite (light blue), lava (red) and lacustrine sediment (yellow).

from these large springs are usually dry. This, together with the Mamaku ignimbrite hydrochemistry signature, implies that these large springs drain the large Mamaku ignimbrite areas upstream that have negligible surface runoff. In the northwest in the Hamurana and Awahou catchments, these springs emerge close to the lake shore within the sediment area (Fig. 5, yellow), indicating that close to the lake shore, due to the more impermeable nature of the intra-caldera sediment, the deeper groundwater flow from the Mamaku ignimbrite is forced to the surface. All of these large springs emerge within the slopes of the sediment formation where sediment layers are thinner and weaker compared to the level area closer to the present lake shore; we infer that the thin nature of the sediments on these slopes allows the water from the underlying ignimbrite to flow to the surface. No large spring occurs in the level area closer to the lake, where sediments are thicker. Also the large Utuhina Spring in the southeast emerges within the slopes of the sediment (Fig. 5), indicating the more impermeable nature of the sediment forcing the groundwater from the Mamaku ignimbrite to the surface in the area of thin sediment layers. The Utuhina Spring emerges below a small local lava dome feature, but the ig- nimbrite signature of the water indicates that this spring is the discharge from the large ignimbrite area southwest of the lava dome feature. The small lava feature may be fractured, discontinuous, or act as a water conduit, allowing water discharge from the ignimbrite behind.

Shallow wells and streams that gain most of their recharge and flow within the lacustrine sediments display a characteristic hydrochemical signature (Fig. 5, yellow circles). Such samples originate from the downstream parts of Waiteti (Wtt) and Ngongotaha (Ngo) streams. The study by Donath et al. (2014) also detected this characteristic hydrochemistry in samples collected with higher spatial resolution in parts of the Ngongotaha subcatchment that are not discussed here.

Hydrochemistry of the water draining the Ngongotaha lava dome west of the lake (Fig. 5, red circles) is inferred to indicate interaction with lava formations. The Ngongotaha dome, similar to the Mamaku ignimbrite, has no drainage via surface flow (stream beds are dry), indicating a highly porous nature, likely due to fractures and pumiceous zones within the dome. Only where the rhyolite dome intercepts the palaeo-lake sediments is the groundwater flow from the lava forced to the surface due to the low permeability of the sediments.

The investigated water discharges from the eastern catchment of Lake Rotorua entirely show geothermal influence in their hydrochemistry composition (not the subject of this study).

The above HCA results give, for the first time, consistent evidence of the link between the main recharge areas in the Mamaku ignimbrite, and the main groundwater discharges into the lake.

\subsection{Hydrochemistry evolution}

In the following two sections hydrochemistry data versus groundwater age is discussed for a better understanding of groundwater processes and geologic versus anthropogenic origin of contaminants.

The groundwater of the Rotorua rhyolite ignimbrite and lava dome aquifers (Fig. 6a) displays high dissolved oxygen (DO), between 5 and $11 \mathrm{mg} \mathrm{L}^{-1}$ (50-100\% of equilibrium with air). There is no trend of decreasing DO with increasing age, indicating that microbial reduction reactions are insignificant in this volcanic aquifer within timescales of the water residence time in the aquifer. Microbial reduction reactions, facilitated by the presence of organic matter or other electron donors (e.g. pyrite), would usually consume the dissolved oxygen in the groundwater. Reduction of oxygen is energetically the most favourable reaction that micro-organisms use in a series of reactions, with the result that other reduction reactions (e.g. denitrification) typically do not occur until most of the dissolved oxygen has been consumed. These reduction reactions take time, and if these reactions are supported by the presence of electron donors in the geologic formation, it is expected that old waters be- 

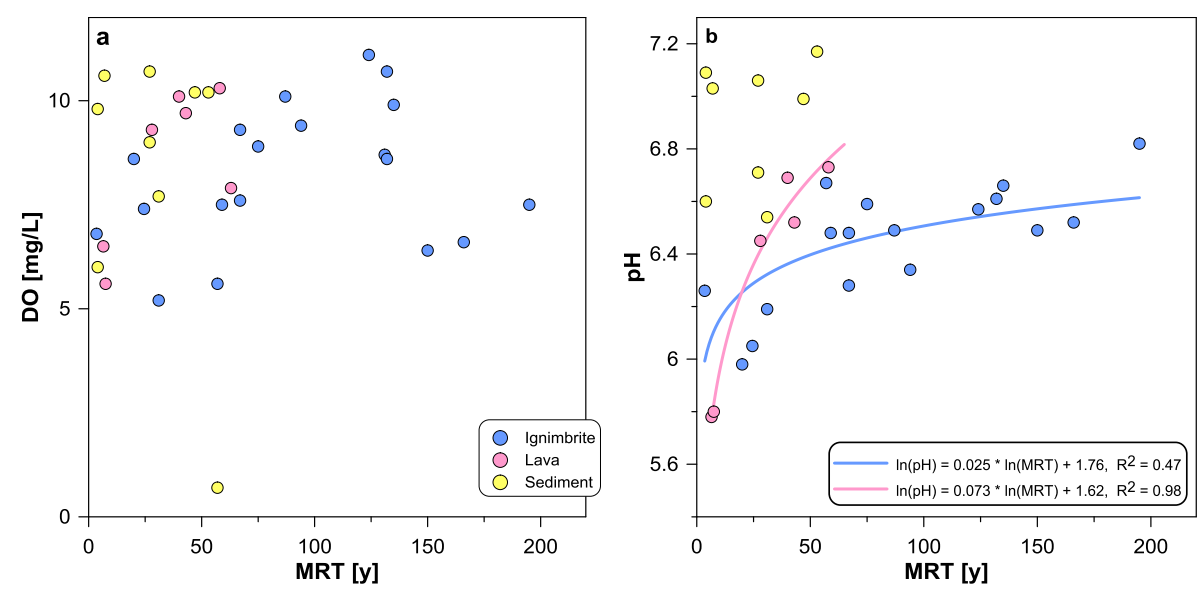

Figure 6. (a) Dissolved oxygen (DO) and (b) pH versus mean residence time (MRT). The colour codes of the samples indicate water from the relevant geologic formation, as indicated by hierarchical cluster analysis.

come increasingly anoxic (e.g. Böhlke et al., 2002; Tesoriero and Puckett, 2011). No trend of decreasing DO with increasing groundwater age was observed, suggesting an absence of significant amounts of electron donors such as organic matter or pyrite in this ignimbrite formation. This is supported by its depositional history as a single large ignimbrite formation without any organic matter involved. Absence of oxygen reduction indicates that there is no potential for significant denitrification reactions in this aquifer system.

Absence of a trend of decreasing DO with increasing groundwater age, but rather constant DO in very young and old groundwater of between 50 and $100 \%$, suggests that the partial oxygen reduction that is observed has occurred in the soil zone, which does contain organic matter, and that once the water has passed the soil zone, no further oxygen reduction processes occur. Only one groundwater sample in the Rotorua catchment was depleted in oxygen (below $1 \mathrm{~m} \mathrm{~L}^{-1}$ ). This is related to the palaeo-lake sediments, suggesting localized deposits of reactive organic matter in these sediments, as would be expected in lake sediments.

The $\mathrm{pH}$ of groundwater usually increases over time due to ongoing hydrogeochemical reactions, resulting in an increasing $\mathrm{pH}$ of groundwater with age. In New Zealand we observed in groundwater an increase from about $\mathrm{pH} 6$ for very young groundwater $(<1$ year) to about $\mathrm{pH} 8$ in very old groundwater ( $>10000$ years) (Morgenstern and Daughney, 2012). For the Rotorua catchment, the groundwater $\mathrm{pH}$ data from lava formations (Fig. 6b) show a sharp increase from $\mathrm{pH} 5.8$ to 6.7 over the age range from 5 to 50 years, with a power law fit of $\ln (\mathrm{pH})=0.073 \times \ln (\mathrm{MRT})+1.62$, $R^{2}=0.98$. For the groundwater from the Mamaku ignimbrite, the $\mathrm{pH}$ increases from just 6.3 to 6.6 over the age range from 0 to 100 years, with a power law fit of $\ln (\mathrm{pH})=0.025 \times \ln (\mathrm{MRT})+1.76, R^{2}=0.47$. The groundwater from the sediment formation shows no clear trend in $\mathrm{pH}$ with groundwater age, but displays higher $\mathrm{pH}$ for rela- tively young water, $\mathrm{pH}$ 6.5-7.2 for water with MRT between 1 and 60 years.

As groundwater becomes more evolved over time due to water-rock interaction, concentrations of phosphorus, silica, bicarbonate and fluoride typically increase due to dissolution of volcanic glass, silicate minerals, carbonates and fluoride likely deposited from the volatile phases in magma exsolved during eruption (Morgenstern and Daughney, 2012). With increasing groundwater age, ion concentrations are expected to increase up to a maximum equilibrium concentration. Groundwater from the sediment formation often follows different or unclear trends compared to the rhyolite ignimbrite and lava formations.

Dissolved reactive phosphate $\left(\mathrm{PO}_{4}-\mathrm{P}\right)$ in groundwater from all three formations, the rhyolite lava and ignimbrite aquifers, and the sediments originating from the same formations, shows excellent correlation with groundwater age (Fig. 7a, black curve), with $\ln \left(\mathrm{PO}_{4-}\right.$ $\mathrm{P})=0.458 \times \ln (\mathrm{MRT})-4.72, R^{2}=0.94$.

Silica $\left(\mathrm{SiO}_{2}\right)$ also shows good correlation with groundwater age for the rhyolite ignimbrite and lava formations (Fig. 7b). The silica concentration of groundwater in lava formations (red circles) increases faster compared to ignimbrite (blue circles). The power fit to the lava data is $\ln \left(\mathrm{SiO}_{2}\right)=0.310 \times \ln (\mathrm{MRT})+2.96$, $R^{2}=0.88$ (red curve), and to the ignimbrite data is $\ln \left(\mathrm{SiO}_{2}\right)=0.238 \times \ln (\mathrm{MRT})+3.05, R^{2}=0.83$ (blue curve). The correlation between silica and groundwater age for the lacustrine sediment aquifers (yellow circles) is rather erratic; high silica concentration can also occur in very young groundwater.

For bicarbonate $\left(\mathrm{HCO}_{3}\right)$, only groundwater samples from the Mamaku ignimbrite show a reasonable correlation with groundwater age, with a power fit of $\ln \left(\mathrm{HCO}_{3}\right)=0.206 \times \ln (\mathrm{MRT})+2.58, R^{2}=0.71$ (Fig. 7c) 

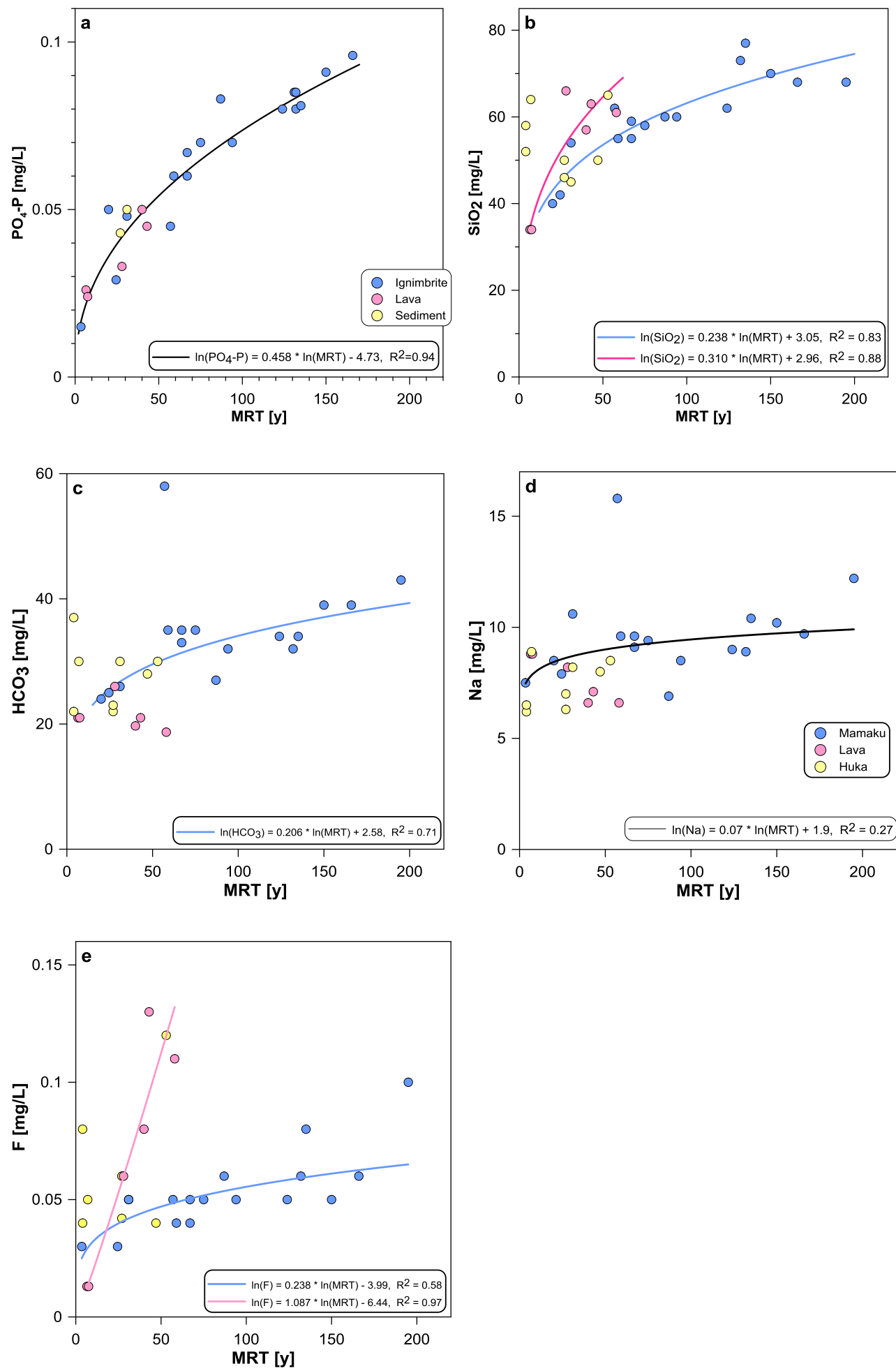

Figure 7. (a) Dissolved reactive phosphate $\left(\mathrm{PO}_{4}-\mathrm{P}\right)$, (b) silica $\left(\mathrm{SiO}_{2}\right)$, (c) bicarbonate $\left(\mathrm{HCO}_{3}\right)$, (d) sodium (Na) and (e) fluoride $(\mathrm{F})$ versus mean residence time (MRT). The sample colour code for all panels is shown in (a), and indicates water origin from the relevant geologic formation, as indicated by hierarchical cluster analysis. 
The high data point at $58 \mathrm{mg} \mathrm{L}^{-1}$ was considered an outlier and not included in the fit.

Sodium $(\mathrm{Na})$ in general also shows increasing concentration with groundwater age because it is part of common minerals and leached from these. But the correlation is poor (Fig. 7d). Note that elevated $\mathrm{Na}$ in young groundwater can also be caused by land-use impacts, as observed in other parts of New Zealand (Morgenstern and Daughney, 2012). Considering the high data point at $15.8 \mathrm{mg} \mathrm{L}^{-1}$ an outlier (it is from the same site considered as an outlier for $\mathrm{HCO}_{3}$ ), the correlation for the data from all three formations is $\ln (\mathrm{Na})=0.07 \times \ln (\mathrm{MRT})+1.9, R^{2}=0.27$.

Fluoride concentrations (F) show good correlations with age for the rhyolite ignimbrite and lava formations (Fig. 7e), even though the trends are masked by the fact that the concentrations are close to the detection limit. Concentrations increase in lava formations significantly faster, with a power fit of $\ln (\mathrm{F})=1.087 \times \ln (\mathrm{MRT})-6.44, R^{2}=0.97$, compared to ignimbrite with $\ln (\mathrm{F})=0.238 \times \ln (\mathrm{MRT})-3.99, R^{2}=0.58$.

In groundwater of the Rotorua catchment (excluding groundwater from the eastern catchment indicating geothermal influence, which is not the subject of this study), the hydrochemistry parameters phosphate, silica, bicarbonate, sodium and fluoride are purely of geologic origin, because they do not display elevated concentrations in young water that was recharged during the time of anthropogenic high intensity land-use activities. The groundwater samples show, for the rhyolite Mamaku ignimbrite and lava formations, excellent correlations across the western and northern Lake Rotorua catchment. The samples in each of these geologic units follow similar trends of hydrochemistry concentration versus mean residence time, indicating the relatively homogeneous nature of these aquifers. Rather erratic trends in water originating from the sediments suggest that these are not a homogeneous formation but rather finely layered lensoidal geologic deposits that vary spatially and support complex or fragmented groundwater systems. Good trends of hydrochemistry versus groundwater age may be an indirect indication of robust age interpretations.

In rhyolite lava formations, geochemical reactions lead to increased $\mathrm{pH}, \mathrm{Si}$, and $\mathrm{F}$ in groundwater significantly faster than in ignimbrite, indicating higher reaction rates for dissolution of these elements from lava formations. While this is important for understanding water-rock interaction, we do not yet have sufficient information on the lithogeochemistry to develop a mechanistic understanding of the reaction processes.

\subsection{Nutrients}

Elevated nutrient levels in surface water cause poisonous algal blooms and lake eutrophication. Presence of both phosphate and nitrate, above a threshold concentration, triggers algae blooms in lakes. Limitation of one of these, P or N, can limit algae blooms. In New Zealand, increasing nutrient loads from high-intensity animal farming and fertilizers have triggered lake eutrophication. In the absence of significant overland runoff, nitrate travels from the land to the lake via the groundwater, which eventually discharges into streams and lakes.

Nutrient concentrations in New Zealand groundwaters from agricultural sources have increased steadily after $\mathrm{Eu}-$ ropean settlement in the early 19th century and with development of the meat industry after 1880 (Morgenstern and Daughney, 2012). In a national context, for groundwater recharged before 1880 at pre-anthropogenic pristine conditions, low nutrient concentrations prevailed (e.g. nitrate $<0.2 \mathrm{mg} \mathrm{L}^{-1} \mathrm{NO}_{3}-\mathrm{N}$ ). In groundwater recharged between 1880 and 1955, nutrient concentrations are slightly elevated due to low-intensity land use. In groundwater recharged after 1955 a sharp increase of nutrient concentrations is observed due to the impact of high-intensity land use after World War II (Morgenstern and Daughney, 2012).

The main nutrients derived from land use in the Rotorua catchment, as indicated by elevated concentrations in young groundwater, are nitrate $\left(\mathrm{NO}_{3}\right)$, sulfate $\left(\mathrm{SO}_{4}\right)$ and potassium $(\mathrm{K})$. These nutrient concentrations are shown in Figs. 8 and $9 \mathrm{a}$ and $\mathrm{b}$ versus mean residence time, also correlated to recharge year (upper $x$-axes). The majority of the chemistry data of the Rotorua data set are from calendar year 2003, therefore mean residence times of about 50 and 125 years correspond to mean groundwater recharge years 1955 and 1880, respectively. Homogeneous nitrate concentrations in discharges from within subcatchments of typically $0.7 \pm 0.2 \mathrm{mg} \mathrm{L}^{-1} \mathrm{NO}_{3}-\mathrm{N}$ indicate that nutrient inputs are derived from diffuse rather than a small number of point sources, pointing to agricultural sources.

Figure 8 also includes data (labelled "other") from the sites in the Lake Rotorua catchment that could not be assigned to one of the HCA clusters because these sites had not been analysed for the full suite of hydrochemical parameters required for input into HCA. In several surveys only nitrate was measured to obtain a higher spatial resolution of the nitrate distribution. The analysis of all hydrochemical parameters, as required for HCA, was mainly undertaken at the large discharges into the lake that contain old water, and only few of these sites contain water young enough to show the impact of recent land-use intensification. Therefore the "other" samples were added to Fig. 8 to better represent younger waters. In addition, samples from the eastern catchment having a geothermal signature are also included in the cluster "other". The geothermal influence is minimal and does not affect the nitrate signature, and hence does not bias the display of results in Fig. 8.

Nitrate concentrations (Fig. 8) in oxic groundwaters with MRT $>125$ years (recharged prior to 1880) in the Rotorua catchment are higher, with up to about $0.7 \mathrm{mg} \mathrm{L}^{-1} \mathrm{NO}_{3}-\mathrm{N}$ (dotted line in Fig. 8) compared to other regions in New Zealand with $0.2 \mathrm{mg} \mathrm{L}^{-1} \mathrm{NO}_{3}-\mathrm{N}$. The reason for elevated nitrate in water despite a high mean residence time is the 


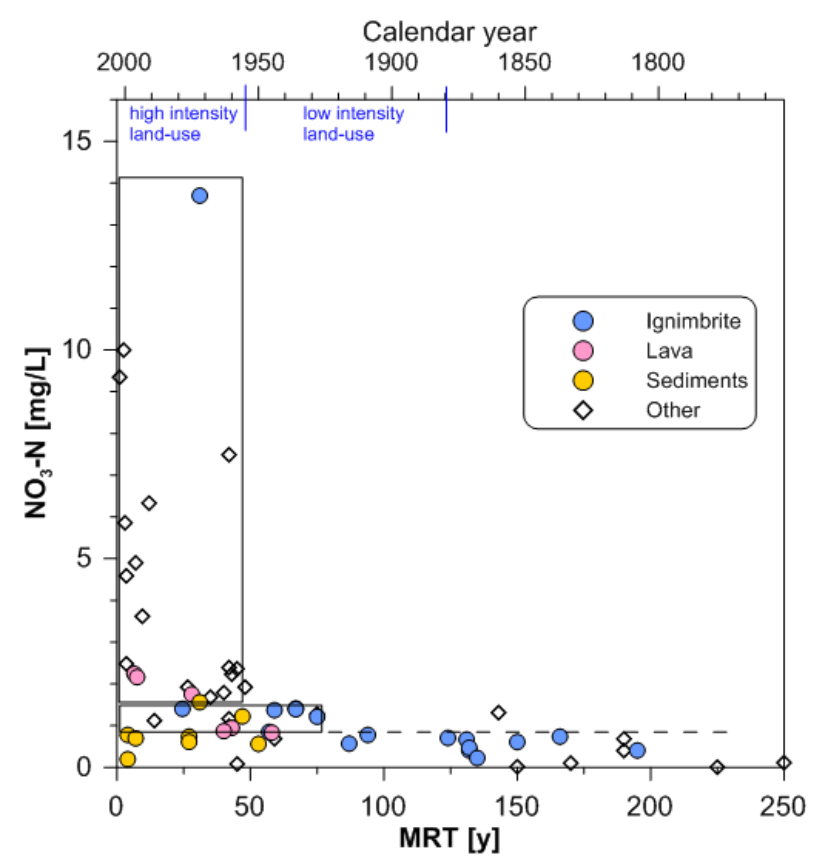

Figure 8. Nitrate $\left(\mathrm{NO}_{3}\right)$ versus mean residence time (MRT). The sample colour code indicates water origin from the relevant geologic formation, as indicated by hierarchical cluster analysis.

high degree of mixing in the groundwater discharges from the highly porous unconfined Rotorua ignimbrite aquifers (see next section). In such aquifer conditions, groundwater from short and long flow paths converge at the groundwater discharges, causing a high degree of mixing of young and old water. For example, groundwater with a MRT as high as 170 years, using an exponential piston flow model with $95 \%$ exponential flow volume within the total flow volume (see next section), contains over $20 \%$ of water recharged after 1955 . This post- 1955 water can contribute significant amounts of nitrate from high-intensity land use, raising the nitrate concentration of the water mix considerably, despite such a long MRT.

A significant increase in nitrate occurred only recently (Fig. 8). Apart from one data point, an increase up to $1.5 \mathrm{mg} \mathrm{L}^{-1} \mathrm{NO}_{3}-\mathrm{N}$ was observed only in water with MRTs of less than 75 years, and a dramatic increase up to $14 \mathrm{mg} \mathrm{L}^{-1} \mathrm{NO}_{3}-\mathrm{N}$ was observed in water with MRTs of less than 50 years. Note the dramatic increase of nitrate in water with MRT $<20$ years, reflecting the increased conversions to dairy farming during the 1980s and 1990s (Rutherford et al., 2011). As the majority of the water discharges into Lake Rotorua are significantly older than a few decades, with MRTs of up to 145 years, the impact of the dairy conversions and their nitrate loads over the recent decades has to a large extent not yet reached the lake. Increased nitrate loads to the lake over the next decades must be expected as these nitrate loads work their way through the large groundwater system and eventually discharge into the streams and lake.
Sulfate and potassium are part of fertilizers and also show elevated concentrations in young groundwater (Fig. 9). Note that sulfate in groundwater in the eastern lake catchment has much elevated concentrations, up to $40 \mathrm{mg} \mathrm{L}^{-1} \mathrm{SO}_{4}$, due to geothermal influence. Groundwater with indications of geothermal influence is not discussed in this study. Also note that sulfate can be biased due to anoxic $\mathrm{SO}_{4}$ reduction. The data shown are, however, not from anoxic groundwater environments. Sulfate and potassium show slightly elevated concentrations, up to a factor of 3 , only in water with MRT $<50$ years, corresponding to water recharged after approximately 1950 . Sulfate concentrations (in $\mathrm{mg} \mathrm{L}^{-1} \mathrm{SO}_{4}$ ) in the Rotorua volcanic aquifers are significantly lower compared to a national survey: pre-anthropogenic concentration of 2 versus 12, and high-intensity land-use concentrations of up to 6 versus 94 for the Rotorua volcanic aquifers and the national survey (Morgenstern and Daughney, 2012), respectively.

Phosphate, in conjunction with nitrate the cause for lake eutrophication, is not elevated in young groundwater (Fig. 7a) despite its frequent application as super-phosphate fertilizers. Absence of elevated $\mathrm{PO}_{4}$ in young groundwater implies that fertilizer phosphate from non-point sources has not yet reached the saturated groundwater systems and is still retained in the soil. This finding is consistent with the usually high P-retention scores for ashfall soils and thick unsaturated zones across this region, which are very efficient at buffering P loss. P-retention in soils was also observed in the New Zealand National Groundwater Monitoring Programme across other soil types (Morgenstern and Daughney, 2012).

The presence of elevated $\mathrm{PO}_{4}$ only in old groundwater indicates that its source is purely due to geological factors, because these waters were recharged before landuse intensification. $\mathrm{PO}_{4}$ concentrations up to $0.1 \mathrm{mg} \mathrm{L}^{-1}$ $\mathrm{PO}_{4}-\mathrm{P}$ are observed, due to phosphate leaching from the rhyolite ignimbrite and lava formations. With most groundwater discharging into Lake Rotorua being very old (MRT $>50$ years), the water has naturally high $\mathrm{PO}_{4}$ concentrations, well above the threshold for primary algae production of ca. $0.03 \mathrm{mg} \mathrm{L}^{-1}$ total phosphate (Dodds, 2007).

The high phosphate load to the lake via groundwater is natural. As the turn-over time of the lake water is only 2.2 years via the high $\mathrm{PO}_{4}$-bearing streams, there is a constantly high $\mathrm{PO}_{4}$ load reaching the lake via all streams. Therefore, the only effective way to limit algae blooms and improve lake water quality in such environments is by limiting the nitrate load.

\subsection{Prediction of future nitrate load}

The water quality of Lake Rotorua has declined continuously over the past 60 years, responding very slowly to historical agricultural and urban development in the catchment, and large amounts of groundwater have insidiously become contaminated over the last 60 years because of the long travel 

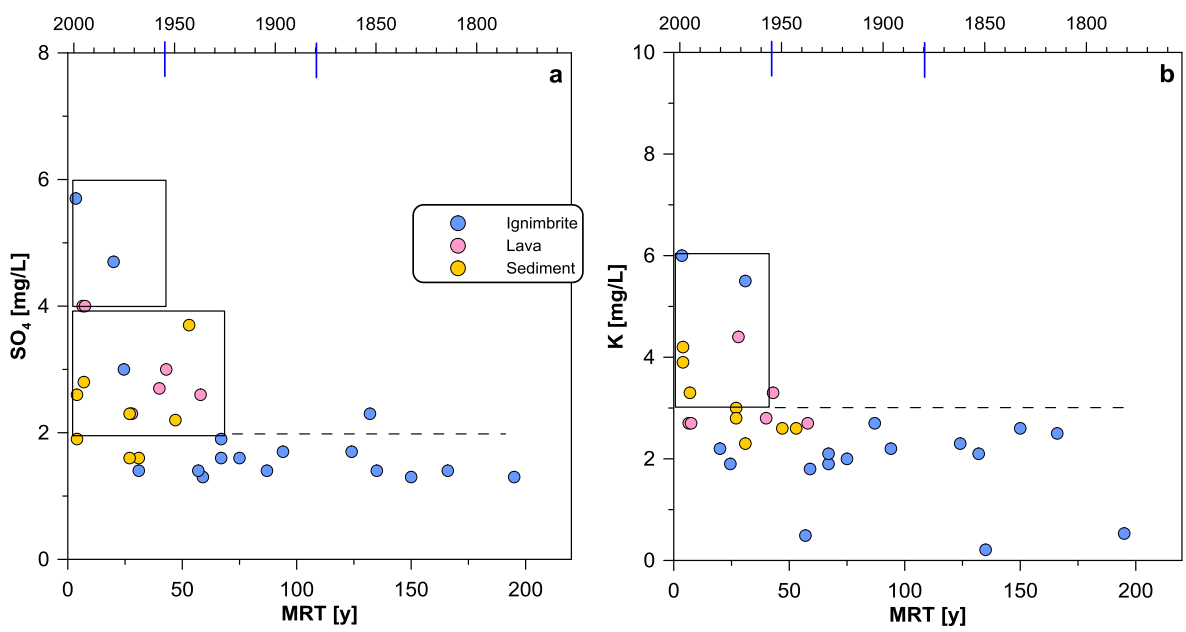

Figure 9. (a) Sulfate $\left(\mathrm{SO}_{4}\right)$ and (b) potassium $(\mathrm{K})$ versus mean residence time (MRT). The sample colour code indicates water origin from the relevant geologic formation, as indicated by hierarchical cluster analysis. The upper axis indicates calendar year.

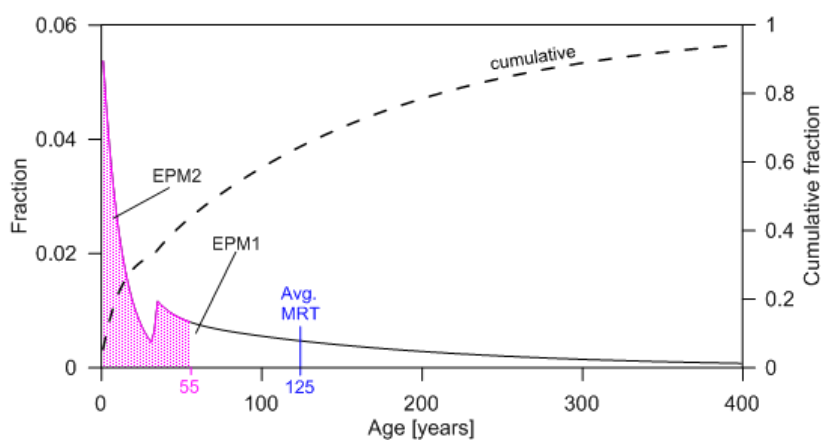

Figure 10. Age distribution for Hamurana Stream (at inflow into Lake Rotorua). The red shaded area indicates the fraction of water that was recharged after land-use intensification. EPM1 and EPM2 are exponential piston flow models.

times through the groundwater system of the Lake Rotorua catchment. The response time of the groundwater system to mitigation action will also be lengthy; it will take similar time frames until the contaminated water is flushed out of the aquifers. To improve lake water quality and define reduction targets for nutrients that affect lake water quality, prediction of future contaminant loads from current and historic activities in the Lake Rotorua catchment are required.

In the previous section we have shown that of the two main contaminants that together cause lake eutrophication, phosphorus is naturally present in the volcanic lake environment, but nitrate from anthropogenic sources has been leaching into the groundwater since the onset of industrial agriculture, delivering increasing nitrate loads to the lake. Figure 8 shows significantly elevated nitrate concentrations in groundwater recharged after 1955.

Due to the large lag time in the groundwater system, these younger groundwaters, with their higher nitrate load, have not yet worked their way fully through the groundwater system. Significant fractions of the groundwaters discharging to the lake are older (Figs. 3 and 4), with MRT $>50$ years, and were recharged before land-use intensification. Therefore the water discharges into the lake are currently still diluted by old pristine water. With the delayed arrival of nitrate from historic land use, which ultimately will discharge from the groundwater system via the springs and streams into the lake, nitrate loads to the lake from historic land-use activities must be expected to increase further in the future. No significant denitrification can be expected in the Rotorua groundwater system (Fig. 6a).

The age distributions functions derived from the tritium time series data in the stream discharges to Lake Rotorua (Table 2) can be used to project the future arrival to the lake of water that was recharged since land-use development in the catchment (Morgenstern and Gordon, 2006). The age distribution function for Hamurana Stream, the largest stream (Table 1), which discharges some of the oldest water to the lake (Fig. 2), is shown in Fig. 10.

Figure 10 shows the two superimposed age distributions of exponential piston flow models: EPM2 with younger water of MRT $=12$ years and EPM1 with significantly older water of MRT $=185$, together with the average MRT $=125$ years between the two models (blue). Only the water younger than 55 years has been recharged after land-use intensification (red shaded) and contains elevated nitrate. The cumulative fraction of land-use impacted water is about $45 \%$, implying that more than half of the water is still pristine old water. After this old water is completely displaced by land-use impacted water, the nitrogen load of Hamurana Stream will approximately double. The projected increase in nitrogen load over time, as derived from the age distribution, is shown in Fig. 11. 


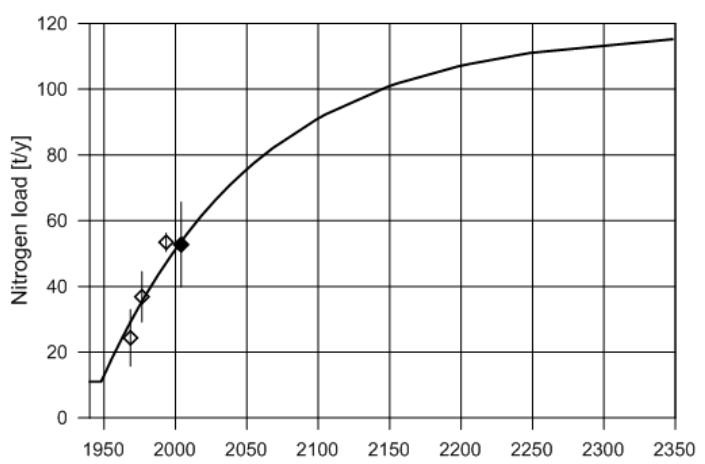

Figure 11. Projected increase over time of nitrogen load to Lake Rotorua from Hamurana Stream.

Nitrate, as opposed to other nitrogen fractions, is clearly the major component of nitrogen in the Rotorua groundwater system (Morgenstern et al., 2004). Concentrations of nitrate in the catchment were low $\left(0.14 \mathrm{mg} \mathrm{L}^{-1} \mathrm{NO}_{3}-\mathrm{N}\right)$ prior to catchment development, as determined from old groundwater (Morgenstern and Gordon, 2006). The prediction of nitrogen load increase is calculated by scaling the nitrogen load currently measured in the stream (full symbol, Fig. 11) according to its fraction of land-use impacted water to the various years over time, using the age distribution (Fig. 10).

Good agreement with average historic monitoring results of nitrogen loads (Rutherford, 2003, hollow symbols in Fig. 11) confirms that the assumptions regarding the baseline concentration and timing of nitrogen input in the catchment are reasonable. Using the age distributions derived for all stream discharges to the lake, we also projected the total nitrogen load increase to Lake Rotorua (Morgenstern and Gordon, 2006). In regard to phosphorus, there are no elevated phosphorus concentrations in young groundwater (Fig. 7a) and the phosphorus load to Lake Rotorua is projected to stay constant, as long as fertilizer phosphate does not break through the soil into the groundwater.

The timescales necessary for the Hamurana Stream to adjust to changes in land-use activities in the catchment are long. Due to the long residence time of the water in the large aquifer system, it takes more than a hundred years for the groundwater discharge to the lake to adjust to changes in land-use activities. These timescales apply to activities that cause contamination, but also to remediation action.

This projection of nitrogen load via the stream is based on actual nitrogen concentrations in the stream (combined with the age of the water) and accounts only for the nitrogen from land-use activities that leaches out of the root zone of agricultural land into the deeper part of the groundwater system. Any nitrogen uptake in the soil is already taken into account.

The above nitrogen prediction is based on constant nitrogen input since catchment development. This trend will, however, be exacerbated by any further intensification of land use within the catchment over recent decades, as this recently recharged water has largely not yet reached the streams.

\section{Conclusions}

This study shows how the isotopic and chemistry signature of groundwater can be used to help determine the sources and the dynamics of groundwater and contaminants that travel with it, in particular in complex groundwater systems that are difficult to characterize using conventional hydrogeologic methods, such as that of the Lake Rotorua catchment. The isotopic and chemistry signatures of the major groundwater-dominated stream discharges to the lake, after passing through the large aquifer system of the catchment, allow us to understand groundwater processes and lag time on a catchment scale.

Tritium time series data and complementary age tracers $\mathrm{SF}_{6}$ and $\mathrm{CFCs}$ can be used to establish age distribution parameters, allowing for understanding of groundwater processes and dynamics, and the timing of groundwater contamination. This is particularly useful in catchments where little information is available on historic land-use activities.

After long-standing controversies (e.g. White et al., 2004; Rutherford et al., 2011), hierarchical cluster analysis of the water chemistry parameters has provided evidence about the recharge areas and hydraulic connections of the large springs near the northern shore of Lake Rotorua. Streams and shallow wells that gain most of their flow and recharge within the lacustrine sediments display a characteristic hydrochemical signature. Hydrochemistry of the water draining the Ngongotaha lava dome also has a characteristic signature due to interaction with lava formations. Only where the lava dome intercepts the palaeo-lake sediments is the groundwater flow from the lava formation forced to the surface due to the low permeability of the sediments. The water from the ignimbrite also displays a characteristic hydrochemical signature. Similarly to the discharges from the lava formation, the water from the ignimbrite discharges near the intercept of the ignimbrite formation with the palaeo-lake sediments, indicating that the groundwater flow from the ignimbrite is forced to the surface due to the low permeability of the sediments. The largest springs, discharging in the northwest of the lake, emerge close to the lake shore within the sediment area, but the ignimbrite signature of these water discharges implies that these springs drain the Mamaku ignimbrite plateau, which has negligible surface runoff, through the lake sediment layers in slope areas where the sediments are thinner and weaker.

Groundwater chemistry and age data show clearly the source of nutrients that discharge with the groundwater into the lake and cause lake eutrophication. Low nitrate concentration in old oxic groundwater and high nitrate concentration in young groundwater recharged after catchment development in the 1950s implies an anthropogenic source of nitrate 
from agricultural activities, while low phosphate $\left(\mathrm{PO}_{4}\right)$ concentrations in young groundwater but high $\mathrm{PO}_{4}$ concentrations in old groundwater imply a geologic source. High $\mathrm{PO}_{4}$ is a natural constituent of the groundwater that discharges via the streams into the lake, and with a turn-over time of the lake water of only 2.2 years, there is a constantly high $\mathrm{PO}_{4}$ load reaching the lake via all streams. Therefore, the only effective way to limit algae blooms and improve lake water quality in such environments is by limiting the nitrate load.

The groundwater in the Rotorua catchment, once it has passed through the soil zone, shows no further decrease in dissolved oxygen over the full range of residence time of the water in the aquifer, indicating an absence of significant microbial reactions due to limitation of electron donors in the aquifer (e.g. organic matter) that could facilitate microbial denitrification reactions (Kendall and McDonnell, 1998; Tesoriero et al., 2007). Nitrate from land-use activities that leaches out of the root zone of agricultural land into the deeper part of the groundwater system is unlikely to undergo any significant degree of reduction through denitrification and must be expected to travel with the groundwater to the lake.

The old age of the water, with mean residence time of $>50$ years for most water discharges to the lake, implies that there is a large lag time for transmission of the nitrate through the groundwater system. Younger groundwaters, with their higher nitrate load, have not yet worked their way fully through the groundwater system. With increasing arrival of this nitrate from historic land uses, a further increase of the nitrate load to the lake must be expected in the future.

The old age and the highly mixed nature of the water discharges imply a very slow and lagged response of the streams and the lake to anthropogenic contaminants in the catchment, such as nitrate. Using the age distribution as deduced from tritium time series data measured in the stream discharges to the lake allows extrapolation of the nutrient load from historic land-use activities into the future. For Hamurana Stream, the largest stream to Lake Rotorua, it takes more than a hundred years for the groundwater-dominated stream discharge to adjust to changes in land-use activities. These time scales apply to activities that cause contamination, but also to remediation action.

Without age information on the groundwater-dominated streams, it would be difficult to obtain such an understanding of groundwater process, groundwater dynamics, and contaminant loads that travel with the groundwater.

Acknowledgements. We thank personnel from Bay of Plenty Regional Council for assistance with sample collection and for provision of some information used in this study, and Eileen McSaveney for editing the paper. This research was supported by funding from the Bay of Plenty Regional Council and the Ministry of Science and Innovation (Contract C05X1002).
Edited by: C. Harman

\section{References}

Bethke, C. M. and Johnson, T. M.: Groundwater age and age dating, Annu. Rev. Earth Pl. Sc., 36, 121-152, 2008.

Beyer, M., Morgenstern, U., and Jackson, B.: Review of dating techniques for young groundwater ( $<100$ years) in New Zealand, J. Hydrol., 53, 93-111, 2014.

Böhlke, J. K. and Denver, J. M.: Combined use of groundwater dating, chemical, and isotopic analyses to resolve the history and fate of nitrate contamination in two agricultural watersheds, Atlantic coastal plain, Maryland, Water Resour. Res., 31, 23192339, 1995.

Böhlke, J. K., Wanty, R., Tuttle, M., Delin, G., and Landon, M.: Denitrification in the recharge area and discharge area of a transient agricultural nitrate plume in a glacial outwash sand aquifer, Minnesota, Water Resour. Res., 38, 1105, doi:10.1029/2001WR000663, 2002.

Broers, H. P.: The spatial distribution of groundwater age for different geohydrological situations in the Netherlands: implications for groundwater quality monitoring at the regional scale, J. Hydrol., 299, 84-106, 2004.

Burger, D. F., Hamilton, D. P., and Pilditch, C. A.: Modelling the relative importance of internal and external nutrient loads on water column nutrient concentrations and phytoplankton biomass in a shallow polymictic lake, Ecol. Model., 211, 411-423, 2011.

Burns, D. A., Plummer, L. N., McDonnell, J. J., Busenberg, E., Casile, G. C., Kendall, C., Hooper. R. P., Freer. J. E., Peters, N. E., Beven, K., and Schlosser, P.: The geochemical evolution of riparian ground water in a forested piedmont catchment, Ground Water, 41, 913-925, 2003.

Burton, W. C., Plummer, L. N., Busenberg, E., Lindsey, B. D., and Gburek, W. J.: Influence of fracture anisotropy on ground water ages and chemistry, Valley and Ridge Province, Pennsylvania, Ground Water, 40, 242-257, 2002.

Cartwright, I. and Morgenstern, U.: Constraining groundwater recharge and the rate of geochemical processes using environmental isotopes and major ion geochemistry: Ovens Catchment, southeast Australia, J. Hydrol., 475, 137-149, 2012.

Cook, P. G. and Herczeg, A. L.: Environmental Tracers in Subsurface Hydrology, Kluwer Academic Publishers, Boston, Dordrech, London, 1999.

Cook, P. G. and Solomon, D. K.: Transport of atmospheric trace gases to the water table: Implication for groundwater dating with CFCs and Krypton 85, Water Resour. Res., 31, 263-270, 1995.

Cook, P. G. and Solomon, D. K.: Recent advances in dating young groundwater: Chlorofluorocarbons, ${ }^{3} \mathrm{H} /{ }^{3} \mathrm{He}$, and ${ }^{85} \mathrm{Kr}$, J. Hydrol., 191, 245-265, 1997.

Cornaton, F. J.: Transient water age distributions in environmental flow systems: The time-marching Laplace transform solution technique, Water Resour. Res., 48, W03524, doi:10.1029/2011WR010606, 2012.

Cornaton, F. J., Park, Y.-J., and Deleersnijder, E.: On the biases affecting water ages inferred from isotopic data, J. Hydrol., 410, 217-225, 2011.

Darling, W. G., Morris, B., Stuart, M. E., and Gooddy, D. C.: Groundwater age indicators from public supplies tapping the 
chalk aquifer of Southern England, J. Chart. Inst. Water Environ. Man., 19, 30-40, 2005.

Daughney, C. J., Jones, A., Baker, T., Hanson, C., Davidson, P., Reeves, R. R., Zemansky, G. M., and Thompson, M.: A national protocol for state of the environment groundwater sampling in New Zealand, Miscellaneous Series 5, Institute of Geological \& Nuclear Sciences, Wellington, New Zealand, 2007.

Daughney, C. J., Morgenstern, U., van der Raaij, R., and Reeves, R. R.: Discriminant analysis for estimation of groundwater age from hydrochemistry and well construction: Application to New Zealand aquifers, Hydrogeol. J., 18, 417-428, 2010.

Dell, P. M.: The effect of afforestation on the water resources of the Mamaku Plateau region, MSc Thesis, University of Waikato, New Zealand, 1982.

Dodds, W. K.: Trophic state, eutrophication and nutrient criteria in streams, Trends Ecol. Evol., 22, 669-676, 2007.

Donath, F. M., Daughney, C. J., Morgenstern, U., Cameron, S. G. and Toews, M. W.: Hydrochemical interpretation of groundwater-surface water interactions at regional and local scales, Lake Rotorua catchment, New Zealand, J. Hydrol. (NZ), in review, 2014.

Eberts, S. M., Böhlke, J. K., Kauffman, L. J., and Jurgens, B. C.: Comparison of particle-tracking and lumped-parameter agedistribution models for evaluating vulnerability of production wells to contamination, Hydrogeol. J., 20, 263-282, 2012.

Edmunds, W. M. and Smedley, P. L.: Residence time indicators in groundwater: the East Midlands Triassic sandstone aquifer, Appl. Geochem., 15, 737-752, 2000.

Glynn, P. D. and Plummer, L. N.: Geochemistry and the understanding of ground-water systems, Hydrogeol. J., 13, 263-287, 2005.

Goode, D. J.: Direct simulation of groundwater age. Wat. Resour. Res., 32, 289-296, 1996.

Gordon, D.: Bay of Plenty, in: Groundwaters of New Zealand, edited by: Rosen, M. R. and White, P. A., New Zealand Hydrological Society, Wellington, New Zealand, 327-354, 2001.

Gusyev, M. A., Abrams, D., Toews, M. W., Morgenstern, U., and Stewart, M. K.: A comparison of particle-tracking and solute transport methods for simulation of tritium concentrations and groundwater transit times in river water, Hydrol. Earth Syst. Sci., 18, 3109-3119, doi:10.5194/hess-18-3109-2014, 2014.

Heaton, T. H. E. and Vogel, J. C.: Excess air in groundwater, J. Hydrol., 50, 201-216, 1981.

Hoare, R. A.: Inflows to Lake Rotorua, J. Hydrol., 19, 49-59, 1980.

Hoare, R. A.: Nitrogen and phosphorus in the catchment of Lake Rotorua. Publication No. 11, Water Quality Centre, Ministry of Works and Development, Hamilton, New Zealand, 1987.

Jurgens, B. C., Böhlke, J. K., and Eberts, S. M.: TracerLPM (Version 1): An Excel ${ }^{\circledR}$ workbook for interpreting groundwater age distributions from environmental tracer data, US Geological Survey Techniques and Methods Report 4-F3, 60 pp., http://ca.water.usgs.gov/user_projects/TracerLPM/ (last access: 4 February 2015), 2012.

Katz, B. G., Böhlke, J. K., and Hornsby, H. D.: Timescales for nitrate contamination of spring waters, northern Florida, USA, Chem. Geol., 179, 167-186, 2001.

Katz, B. G., Chelette, A. R., and Pratt, T. R.: Use of chemical and isotopic tracers to assess nitrate contamination and ground-water age, Woodville Karst Plain, USA, J. Hydrol., 289, 36-61, 2004.
Katz, B. G., Plummer, L. N., Busenberg, E., Revesz, K. M., Jones, B. F., and Lee, T. M.: Chemical evolution of groundwater near a sinkhole lake, northern Florida 2. Chemical patterns, mass transfer modelling, and rates of mass transfer reactions, Water Resour. Res., 31, 1565-1584, 1995.

Kendall, C. and McDonnell, J. J. (Eds.): Isotope Tracers in Catchment Hydrology, Elsevier Science B. V., Amsterdam, 519-576, 1998.

Leonard, G. S., Begg, J. G., Wilson, C. J. N. (Compilers): Geology of the Rotorua area, Institute of Geological and Nuclear Sciences $1: 250,000$ geological map 5, GNS Science, Lower Hutt, New Zealand, 2010.

Lock, K. and Kerr, S.: Nutrient trading in Lake Rotorua: Social, cultural, economic and environmental issues around a nutrient trading system, Motu Manuscript MEL0319, Motu Economic and Public Policy Research, Wellington, New Zealand, 2008.

MacDonald, A. M., Darling, W. G., Ball, D. F., and Oster, H.: Identifying trends in groundwater quality using residence time indicators: An example from the Permian aquifer of Dumfries, Scotland, Hydrogeol. J., 11, 504-517, 2003.

Maloszewski, P. and Zuber, A.: Determining the turnover time of groundwater systems with the aid of environmental tracers, 1. Models and their applicability, J. Hydrol., 57, 207-231, 1982.

Maloszewski, P. and Zuber, A.: Influence of matrix diffusion and exchange reactions on radiocarbon ages in fissured carbonate aquifers, Water Resour. Res., 27, 1937-1945, 1991.

McDonnell, J. J., McGuire, K., Aggarwal, P., Beven, K., Biondi, D., Destouni, G., Dunn, S., James, A., Kirchner, J., Kraft, P., Lyon, S., Maloszewski, P., Newman, B., Pfister, L., Rinaldo, A., Rodhe, A., Sayama, T., Seibert, J., Solomon, K., Soulsby, C., Stewart, M., Tetzlaff, D., Tobin, C., Troch, P., Weiler, M., Western, A., Wörman, A., and Wrede, S.: How old is streamwater? Open questions in catchment transit time conceptualization, modelling and analysis, Hydrol. Process., 24, 1745-1754, 2010.

McGuire, K. J., DeWalle, D. R., and Gburek, W. J.: Evaluation of mean residence time in subsurface waters using oxygen- 18 fluctuations during drought conditions in the mid-Appalachians, J. Hydrol., 261, 132-149, 2002.

Milner, D. M., Cole, J. W., and Wood, C. P.: Mamaku Ignimbrite: a caldera-forming ignimbrite erupted from a compositionally zoned magma chamber in Taupo Volcanic Zone, New Zealand, J. Volcanol. Geoth. Res., 122, 243-264, 2003.

Molson, J. W. and Frind, E. O.: How old is the water? Simulating groundwater age at the watershed scale, IAHS Publ., 297, 482488, 2005.

Moore, K. B., Ekwurkel, B., Esser, B. K., Hudson, G. B., and Moran, J. E.: Sources of groundwater nitrate revealed using residence time and isotope methods, Appl. Geochem., 21, 10161029, 2006.

Morgenstern, U.: Assessment of age distribution in groundwater, in: Proceedings of the 2nd Asia Pacific Association of Hydrology and Water Resources Conference, vol. 1, 5-8 July 2004, Singapore, 580-587, 2004.

Morgenstern, U. and Daughney, C. J.: Groundwater age for identification of baseline groundwater quality and impacts of landuse intensification - The National Groundwater Monitoring Programme of New Zealand, J. Hydrol., 456-457, 79-93, 2012.

Morgenstern, U. and Gordon, D.: Prediction of Future Nitrogen Loading to Lake Rotorua, GNS Science Re- 
port 2006/10, Lower Hutt, New Zealand, GNS Science, 28 pp., available at: http://www.boprc.govt.nz/media/33280/ Report-060600-PredictionofFutureNloadLRotorua.pdf (last access: 4 February 2015), 2006.

Morgenstern, U. and Taylor, C. B.: Ultra Low-level tritium measurement using electrolytic enrichment and LSC, Isotop. Environ. Health Stud., 45, 96-117, 2009.

Morgenstern, U., Reeves, R., Daughney, C., Cameron, S., and Gordon, D.: Groundwater age and Chemistry, and Future Nutrient Load for Selected Rotorua Lakes Catchments, Institute of Geological \& Nuclear Sciences Science Report 2004/31, GNS Science, Lower Hutt, New Zealand, 74 pp., available at: http://www.boprc.govt.nz/media/32425/GNS-091118 (last access: 4 February 2015), 2004.

Morgenstern, U., Stewart, M. K., and Stenger, R.: Dating of streamwater using tritium in a post nuclear bomb pulse world: continuous variation of mean transit time with streamflow, Hydrol. Earth Syst. Sci., 14, 2289-2301, doi:10.5194/hess-14-22892010, 2010.

Morgenstern, U., van der Raaij, R., and Baalousha, H.: Groundwater flow pattern in the Ruataniwha Plains as derived from the isotope and chemistry signature of the water, GNS Science Report 2012/23, GNS Science, Lower Hutt, New Zealand, 50 pp., available at: http://www.gns.cri.nz/static/pubs/2012/SR_ 2012-023.pdf (last access: 5 February 2015), 2012.

Morris, B., Stuart, M. E., Darling, W. G., and Gooddy, D. C.: Use of groundwater age indicators in risk assessment to aid water supply operational planning, J. Chart. Inst. Water Environ. Man., 19, 4148, 2005.

New Zealand Ministry of Health: Drinking-water standards for New Zealand 2005 (revised 2008), Ministry of Health, Wellington, New Zealand, 2008.

Rosen, M. R., Milner, D., Wood, C. P., Graham, D., and Reeves, R.: Hydrogeologic investigation of groundwater flow in the Taniwha Springs area. Institute of Geological and Nuclear Sciences Client Report 72779C.10, GNS Science, Lower Hutt, New Zealand, 1998.

Rutherford, J. C., Pridmore, R. D., and White, E.: Management of phosphorus and nitrogen inputs to Lake Rotorua, New Zealand, J. Water Resour. Pl. Manage., 115, 431-439, 1989.

Rutherford, K.: Lake Rotorua Nutrient Load Targets, NIWA Client Report HAM2003-155, National Institute of Water and Atmospheric Research, Hamilton, New Zealand, 2003.

Rutherford, K., Tait, A., Palliser, C., Wadhwa, S., and Rucinski, D.: Water balance modelling in the Lake Rotorua catchment, NIWA Client Report HAM2008-048, National Institute of Water and Atmospheric Research, Hamilton, New Zealand, 2008.

Rutherford, K., Palliser, C., and Wadhwa, S.: Nitrogen exports from the Lake Rotorua catchment - calibration of the ROTAN model, NIWA Client Report HAM2009-019, National Institute of Water and Atmospheric Research, Hamilton, New Zealand, 2009.

Rutherford, K., Palliser, C., and Wadhwa, S.: Prediction of nitrogen loads to Lake Rotorua using the ROTAN model, NIWA Client Report HAM2010-134, National Institute of Water and Atmospheric Research, Hamilton, New Zealand, 2011.

Spinks, K. D., Acocella, V., Cole, J. W., and Bassett, K. N.: Structural control of volcanism and caldera development in the transtensional Taupo Volcanic Zone, New Zealand, J. Volcanol. Geoth. Res., 144, 7-22, 2005.
Stewart, M. K. and Morgenstern, U.: Age and source of groundwater from isotope tracers, in: Groundwaters of New Zealand, edited by: Rosen, M. R. and White, P. A., New Zealand Hydrological Society, Wellington, New Zealand, 161-183, 2001.

Stewart, M. K. and Thomas, J. T.: A conceptual model of flow to the Waikoropupu Springs, NW Nelson, New Zealand, based on hydrometric and tracer $\left({ }^{18} \mathrm{O}, \mathrm{Cl},{ }^{3} \mathrm{H}\right.$ and CFC $)$ evidence, Hydrol. Earth Syst. Sci., 12, 1-19, doi:10.5194/hess-12-1-2008, 2008.

Stewart, M. K., Mehlhorn, J., and Elliott, S.: Hydrometric and natural tracer $\left({ }^{18} \mathrm{O}\right.$, silica, ${ }^{3} \mathrm{H}$ and $\left.\mathrm{SF}_{6}\right)$ evidence for a dominant groundwater contribution to Pukemanga Stream, New Zealand, Hydrol. Process., 21, 3340-3356, 2007.

Stewart, M. K., Morgenstern, U., and Mc Donnell, J. J.: Truncation of stream residence time: how the use of stable isotopes has skewed our concept of streamwater age and origin, Hydrol. Process., 24, 1646-1659, 2010.

Taylor, C. B. and Stewart, M. K.: Hydrology of the Rotorua Geothermal Aquifer, NZ, in: Isotope Techniques in Water Resources Development, IAEA STI/PUB/757, IAEA, Vienna, 2545, 1987.

Tesoriero, A. J. and Puckett, L. J.: $\mathrm{O}_{2}$ reduction and denitrification rates in shallow aquifers, Water Resour. Res., 47, W12522, doi:10.1029/2011WR010471, 2011.

Tesoriero, A. J., Saad, D. A., Buriow, K. R., Frick, E. A., Puckett, L. J., Barbash, J. E.: Linking groundwater age and chemistry data along flow-paths: implications for trends and transformations of nitrate and pesticides, J. Contam. Hydrol. 94, 139-155, 2007.

van der Raaij, R. and Beyer, M.: Use of CFCs and $\mathrm{SF}_{6}$ as groundwater age tracers in New Zealand, J. Hydrol., accepted, 2014.

Weissman, G. S., Zhang, Y., LaBolle, E. M., and Fogg, G. E.: Dispersion of groundwater age in an alluvial aquifer, Water Resour. Res., 38, 16.1-16.8, 2002.

White, P. A. and Rutherford, K.: Groundwater catchment boundaries of Lake Rotorua, Institute of Geological \& Nuclear Sciences Consultancy Report 2009/75LR, GNS Science, Lower Hutt, New Zealand, 2009.

White, P. A., Cameron, S. G., Kilgour, G., Mroczek, E., Bignall, G., Daughney, C., and Reeves, R. R.: Review of groundwater in the Lake Rotorua catchment. Institute of Geological \& Nuclear Sciences Consultancy Report 2004/130, GNS Science, Lower Hutt, New Zealand, 2004.

White, P. A., Kilgour, G. N., Hong, T., Zemansky, G., and Wall, M.: Lake Rotorua groundwater and Lake Rotorua nutrients Phase 3 science programme technical report, Institute of Geological \& Nuclear Sciences Consultancy Report 2007/220, GNS Science, Lower Hutt, New Zealand, 2007.

Wilson, C. J. N., Houghton, B. F., McWilliams, M. O., Lanphere, M. A., Weaver, S. D., and Briggs, R. M.: Volcanic and structural evolution of Taupo Volcanic Zone: A review, J. Volcanol. Geoth. Res., 68, 1-28, 1995.

Zoellmann, K., Kinzelbachach, W., and Fulda, C.: Environmental tracer transport $\left({ }^{3} \mathrm{H}\right.$ and $\left.\mathrm{SF}_{6}\right)$ in the saturated and unsaturated zones and its use in nitrate pollution management, J. Hydrol., 240, 187-205, 2001.

Zuber, A., Witczak, S., Rózanìski, K., Sìliwka, I., Opoka, M., Mochalski, P., Kuc, T., Karlikowska, J., Kania, J., JackowiczKorczynìski, M., and Dulinìski, M.: Groundwater dating with ${ }^{3} \mathrm{H}$ and $\mathrm{SF}_{6}$ in relation to mixing patterns, transport modelling and hydrochemistry, Hydrol. Process., 19, 2247-2275, 2005 